\title{
International Reserves and the Composition of Foreign Equity Investment
}

\author{
Xingwang Qian* and Andreas Steiner**
}

September 2013

\begin{abstract}
We study the effect of central banks' international reserve hoardings on the composition of foreign equity investment. Specifically we examine whether reserves affect the share of foreign portfolio equity investment (PEI) in total foreign equity investment, which includes both PEI and foreign direct investment (FDI). Foreign investors' decisions regarding the location and the type of equity capital investment might be influenced by a country's level of international reserves. In a simple theoretical model, we show that higher reserves, thanks to their ability to lower exchange rate risk, reduce the risk premium of PEI. Hence, higher reserves are expected to increase the inflow of PEI relative to FDI. We test this hypothesis for a sample of 76 developing countries during the period 1980-2010 using different estimation methods, model specifications and data samples. The results suggest that higher levels of reserves are associated with a larger share of PEI relative to FDI. This result points to a collateral benefit of reserves that has been neglected so far: Reserves may contribute to develop domestic financial markets and facilitate domestic firms' access to foreign portfolio equity financing. In addition, we find a strong negative effect of the global financial crisis beginning in 2008 on the share of PEI, which confirms the hypothesis that PEI is more crisis-dependent than FDI.
\end{abstract}

Keywords: International Reserves, Capital Inflows, Equity Capital JEL Classification Numbers: F3, F4, O16

Acknowledgments: We thank Joshua Aizenman, Menzie Chinn, Frank Westermann, and two anonymous referees for helpful comments and advice. We also thank participants of seminars at the University of Osnabrueck, the Graduate School of Economics and Business, University of Groningen, the 7th Annual APEA Conference in Busan, the 4th Annual Conference "Emerging Economies in Globalized Financial Markets" in Halle, the EEA-ESEM meeting in Malaga, the Annual Conference of the German Research Committee on Development Economics, and HKIMR for their valuable comments and suggestions. We are very grateful to Philip Lane and Christian Lundblad for sharing data.

* Xingwang Qian, Economics and Finance Department, SUNY Buffalo State, Buffalo, NY 14222, USA, Email: qianx@buffalostate.edu. Tel.: 1(716) 8786031.

** Andreas Steiner, Institute of Empirical Economic Research, University of Osnabrueck, 49069 Osnabrück, Germany, Email: asteiner@uni-osnabrueck.de. Tel.: +49 541 9692556; fax: +49 5419692757. 


\section{Introduction}

The global financial crisis of 2008-10 has highlighted the flip side of financial globalization: Global interdependencies facilitated the spread of the crisis around the globe. This has renewed the interest in the role played by different types of capital flows during periods of financial distress. ${ }^{1}$ Moreover, the discussion of how policies can influence the composition of capital inflows and hence affect economic growth has been intensified. ${ }^{2}$

In emerging markets international reserves have been employed as an important monetary policy tool to signal domestic financial health, to self-insure against financial crises, and to demonstrate a country's ability to stabilize its exchange rate. International reserves may affect the behavior of foreign investors through two channels: First, the accumulation of reserves creates expectations that the central bank stabilizes the exchange rate in the future. As a consequence, market participants discount exchange rate risk. Second, reserves reduce the perceived risk of the investment because they create bailout expectations. In the face of a sovereign debt crisis or a liquidity crisis involving large domestic companies or banks, the central bank may liquidate its international reserves to bail out external creditors. Moreover, reserves are used to cope with negative shocks and capital flight (see, among others, Aizenman and Marion, 2004). Although it constitutes a transfer to foreigners, this policy may be welfare enhancing because it mitigates the domestic costs of partial default and helps to maintain a country’s access to external sources of financing. In a nutshell, reserve hoardings are perceived as an implicit insurance of investors and may enhance capital inflows. $^{3}$

\footnotetext{
${ }^{1}$ Appendix A provides a brief review of the literature.

${ }^{2}$ See, among others, Milesi-Ferretti and Tille (2011); Ostry et al. (2010); Reinhart and Rogoff (2011) and Tong and Wei (2011).

${ }^{3}$ Both pegged exchange rates and bailout expectations are considered to be contributing factors to the Asian financial crisis of 1997 (see, among others, Corsetti et al., 1999).
} 
This implicit insurance value of reserves might affect the decision process of borrowers and creditors engaged in cross-border capital flows, for instance, the choice between domestic and foreign borrowing, the currency denomination of external debt, the form of financing (FDI, PEI or debt) and the time-horizon of the debt relationship. ${ }^{4}$

This paper focuses on the form of external financing, particularly the impact of international reserves on the composition of foreign equity investment, namely portfolio equity investment (PEI) and foreign direct investment (FDI) ${ }^{5}$. In particular, we examine whether the level of reserves affects the share of PEI in total foreign equity capital investment.

FDI and PEI are the two most important components of the global capital market, particularly in emerging markets. Together they accounted for about $64 \%$ of capital flows to emerging markets in 2010 (McKinsey Global Institute, 2011). They provide many benefits to both investors and the recipient country: They enable investors to diversify their portfolio and reduce investment risks. They also propel the integration of the global capital market, which arguably contributes to the spread of best practices of corporate governance, legal practice, and accounting standards, and has a disciplinary effect, which limits a government's ability, especially in developing countries, to pursue bad policies.

FDI and PEI, individually, bring pros and cons to both investors and the host country. On the one hand, FDI contributes to the transfer of advanced technologies, brings along management know-how and improves market accessibility. On the other hand, due to increased competition, it could crowd out local industries. PEI provides market liquidity for economic growth, but it may come to a sudden stop during financial stress due to its volatile

\footnotetext{
${ }^{4}$ See Hale (2007) and Tirole (2003) for the form of financing. The currency denomination of external debt is usually examined in the context of the exchange rate regime, whose credibility, in turn, depends on the level of reserves (see Burnside et al., 2001; Martínez and Werner, 2002).

${ }^{5}$ By convention, an investment is considered as FDI when the equity share exceeds $10 \%$ of the voting stock. FDI can be in the form of a new production facility (greenfield investment) or a major shareholding in an existing firm (M\&A activities). PEI refers to foreigners directly purchasing stocks in the local stock market with the total share being below $10 \%$.
} 
nature. From the point of view of foreign equity investors, FDI helps to explore local markets, hence reap high returns; but it is hard to liquidize (fire-sale) during episodes of economic downturn. Thus investors may suffer from substantial losses. In contrast, PEI is easy to liquidize but has to pay an extra risk premium due to asymmetric information (Goldstein and Razin, 2006).

These different effects have raised many policy related issues. How to harness those pros and cons to benefit the most out of both FDI and PEI? What determines the composition of FDI and PEI? Why do some countries rely more on FDI, while others intend to have more PEI? If desired, what policies can alter the composition?

Despite the increasing interest in the composition of foreign equity investment (Goldstein et al., 2010; Kirabaeva and Razin, 2013; Lane and Milesi-Ferretti, 2000), little work has been done on how international reserves affect this composition. This paper is the first to evaluate the relationship between reserves and the composition of foreign equity investment both theoretically and empirically and to draw some policy implications. We show formally that higher reserves reduce the risk premium of PEI and hence make PEI more attractive relative to FDI. We then confront our hypothesis with the data: We conduct a panel data analysis for a set of developing countries over the period 1980-2010.

As an illustration of the data, Figure 1 shows the bivariate relationship between reserves and the composition of equity investment in the sample-averaged data from 1980 to 2010 and two individual countries, namely Brazil and Malaysia. It provides some anecdotal evidence that both variables are positively associated.

To anticipate the results, we find that a high level of international reserves in a developing country is associated with a high share of PEI in total foreign equity capital investment. This result is robust across different model specifications including different 
country samples, alternate sets of control variables, and across estimation procedures, namely static and dynamic panel data regressions.

This paper bridges the gap between two major strands of the literature, which have not been considered together so far: First, it relates to the literature that evaluates the costs and benefits of the accumulation of international reserves. Second, it links to papers that examine the determinants and consequences of the composition of foreign capital flows.

The paper is organized as follows: In section 2, we describe the possible theoretical mechanism through which international reserves affect the composition of foreign equity investment. Section 3 empirically studies our theoretical hypothesis for different country samples and estimators. We briefly describe the implications of the composition of foreign equity investment for a recipient developing country in Section 4. Section 5 concludes.

\section{Theoretical considerations}

What are plausible channels through which international reserves might affect the composition of foreign equity investment? This section presents an illustrative theoretical model of the links between reserves and the composition of foreign equity investment.

We build the model from the perspective of a risk-averse investor who considers equity investments internationally. The return of foreign equity investments, both FDI and PEI, depends on common country-specific factors and risks ${ }^{6}$ : First, the return of the equity investment depends on the stance of the business cycle (see Fama, 1981). Second, macroeconomic policies like trade policy, labor market regulations and exchange rate policy affect the competitiveness of the firm in international markets and its return. Third, political instability, the risk of expropriation and enforcement problems may reduce the return of both

\footnotetext{
${ }^{6}$ We focus on macroeconomic risks in this paper. There exist firm-specific risks that affect the return of an individual investment. However, we do not consider this in our analysis as our macroeconomic model is based on a representative firm.
} 
FDI and PEI. Fourth, devaluations increase the competitiveness of local production and may enhance returns of both FDI and PEI.

Compared to home equity investments and FDI, PEI is subject to an important additional risk factor: exchange rate risk. The return of FDI is primarily related to economic fundamentals of the host country, while the return of PEI tends to be influenced by exchange rate fluctuation in that the value of PEI shares, expressed in foreign currency, decreases with the depreciation of the home currency while the value of real assets is unaffected. We therefore single out the expected exchange rate risk and examine how exchange rate risk affects FDI and PEI differently.

Our argumentation is based on the empirical finding that stock markets are negatively affected by devaluations. Such an adverse effect is stronger expressed in foreign currency units than in domestic currency. Hence, foreign investors are more adversely affected. ${ }^{7}$ Malliaropulos (1998) shows in a theoretical model that a real depreciation decreases the price of domestic stocks relative to foreign ones. Lane and Milesi-Ferretti (2008) argue that the relatively small cross-border holdings of portfolio equity assets and liabilities in emerging markets compared to advanced economies are due to the presence of high currency risk in emerging markets. It is a well-documented fact that exchange rate returns and stock market returns are positively correlated. Findings with respect to the direction of causality, however, are ambiguous. $^{8}$

This stock market behavior around devaluations is more relevant for PEI compared to FDI. First, individual PEI investors execute their transactions at the stock market and depend on its prices. The purchase or sale of a foreign direct investment, especially a greenfield or

\footnotetext{
${ }^{7}$ Glen (2002), who studies 24 devaluation episodes in emerging markets, finds a negative relationship between devaluations and stock market returns. This effect is stronger and more persist in foreign currency than in domestic currency units. Similarly, Wilson et al. (2000), who study the stock market around the 1994 Mexican Tequila crisis, find that the decline in the stock values was much stronger in dollar terms than in domestic currency units. Patro et al. (2013) also confirm significant abnormal negative returns of stock markets around devaluation episodes.

${ }^{8}$ Granger et al. (2000) find that causality between stock markets and exchange rates runs in both directions.
} 
merger activity, may be executed without stock market involvement. Hence, prices may be de-linked from stock market prices and are more dependent on the value of real assets while PEI investors’ depend on dividends and share prices. Second, for existing foreign direct investments, the owner's return is measured by its real yield, not stock market returns. This may suggest that currency crises mainly affect the behavior of PEI, while FDI is resilient to exchange rate devaluation.

International reserves can be used to signal financial health of an economy, to stabilize the exchange rate, and to smooth necessary adjustments of the exchange rate and consumption in the presence of shocks. Thus, they reduce the probability of incurring an output-loss currency crisis (Aizenman and Marion, 2004). Further, reserves can mitigate the extent and severity of a crisis (Obstfeld et al., 2009). In addition, reserves have been found to alleviate the impact of terms-of-trade shocks on the real exchange rate (Aizenman and RieraCrichton, 2008), reducing the pass-through from terms-of-trade shocks on stock market returns.

To isolate the effect of exchange rate risk, we abstract from all other factors that affect the return of foreign equity investment and assume that they have the same effect on both FDI and PEI. All common risk factors are subsumed into $\rho$, the risk premium associated with foreign equity investment in developing countries. Furthermore, since FDI is resilient to currency crises, we treat its return as the benchmark and focus on how currency crises affect the return of PEI.

We model the return of PEI as an interest-rate-like yield in an environment of possible currency crises. This modeling strategy is consistent with the corporate finance approach to calculate stock prices and returns: In corporate finance, the share price equals the discounted stream (present value) of expected dividend payments. Alternatively, one may link the share 
price directly to the value of the firm, which depends on investment, production function and productivity shocks (Kirabaeva and Razin, 2013).

Consider the following no arbitrage condition according to which the expected PEI rate of return measured in the investor's currency equals the risk-free world interest rate $r^{f}$ plus the risk premium in developing countries $\rho$ :

$$
\left(1+r^{P E I}\right) \cdot \frac{E_{t+1}}{E_{t}}=\left(1+r^{F D I}\right)=\left(1+r^{f}+\rho\right)
$$

where $\left(r^{P E I}\right)$ is the expected PEI rate of return expressed in the currency of the equity investment. $E$ is the nominal exchange rate such that $E_{t+1} / E_{t}$ accounts for changes in the exchange rate. $t$ denotes the time index. $r^{F D I}$ is the expected FDI rate of return. We define the risk-adjusted world return as $r=r^{f}+\rho$. Equation (1) essentially states that, due to the no arbitrage condition, the risk-adjusted returns of three forms of investment (PEI and FDI in developing countries, and investment in the world market) should be equal. If a risk of exchange rate devaluation exists, $r^{P E I}$ has to be larger to make investors indifferent between these three forms of investment.

The probability of a currency-crisis induced devaluation is given by $p$. Assume that with probability $(1-p)$ the nominal exchange rate is constant. ${ }^{9}$ Hence, equation (1) can be expressed as:

$$
(1-p) \cdot\left(1+r^{P E I}\right)+p q \cdot\left(1+r^{P E I}\right)=(1+r)
$$

where $q=\frac{E_{t+1}}{E_{t}}$ can be considered as the recovery ratio with $q<1$ when the local currency devaluates in a currency crisis.

\footnotetext{
${ }^{9}$ For model simplicity, we assume 1-p to be the probability of a constant exchange rate. The model can be easily extend to the scenario of appreciation, in which $(1-p) \cdot \theta \cdot\left(1+r^{P E I}\right)+p q \cdot\left(1+r^{P E I}\right)=(1+r)$, where $\theta$ is a constant and $\theta>1$. The model result is the same as the one presented in the text.
} 
Equation (2) can be solved for the risk premium $(R P)$ of PEI, which is defined as the difference between the implicit interest rate on PEI and the risk-adjusted world interest rate $\left(r^{P E I}-r\right)$ :

$$
R P=\left(1+r^{P E I}\right) \cdot(p-p q)
$$

Since $r^{F D I}=r, R P$ can alternatively be considered as the spread of the PEI return relative to FDI.

Theoretical models and empirical evidence suggest that both the probability of devaluation (Aizenman and Marion, 2004; Frankel and Saravelos, 2012; Li and Rajan, 2009) and its extent in case of a crisis (De Gregorio and Lee, 2004; Obstfeld et al., 2009) depend negatively on the level of international reserves. In the light of these findings we assume that $p$ decreases in the level of reserves and $q$ is positively associated with reserves.

The partial derivative of the risk premium with respect to international reserves is given by

$$
\frac{\partial R P}{\partial I R}=\left(1+r^{P E I}\right) \cdot\left(p_{I R}(1-q)-p q_{I R}\right)<0
$$

where the index $I R$ indicates the first derivative with respect to international reserves. By assumption, $p_{I R}<0$ (higher reserve holdings lower the probability of a currency crisis) and $q_{I R}>0$ (higher reserves holdings increase the recovery ratio).

The theoretical result suggests that higher levels of reserves reduce the risk premium of PEI because higher reserves reduce both the probability and the extent of currency devaluation. With the lower risk premium, PEI is ceteris paribus a more attractive form of investment for foreign investors in a developing country. In Appendix B we formally derive the effect of international reserves - via a lower risk premium - on the ratio of PEI and FDI.

Thus, we postulate that higher international reserves increase the share of PEI in total foreign equity investment. However, our hypothesis does not necessarily imply that PEI 
substitutes for FDI. It rather states that international reserves help countries to attract a higher ratio of PEI to FDI. ${ }^{10}$

Admittedly, there is a caveat in our theory discussion. In our model, we use the return of FDI as benchmark. By doing that, we implicitly assume that the return of FDI is less affected by a currency crisis because of the finding that it is rather resilient to crises. However, there might be exceptions where this is not the case. There are instances where a foreign investor may liquidate (or fire-sale) her FDI in a currency crisis due to depressed future output expectations. In such a fire-sale, the price is usually deeply discounted compared to the fair-market price in tranquil times (Acharya et al., 2011; Aguiar and Gopinath, 2005). It is possible that the loss in such a fire-sale is larger than that of a PEI sale in some individual cases. However, at the macro level we expect such situations to be rare.

\section{Empirical analysis}

In this section, we empirically test the hypothesis derived in the previous section. Our sample includes 76 developing countries and ranges from 1980 to 2010 with the last year determined by data availability. Besides the full sample we examine the subsamples of natural resourcerich countries and other developing countries excluding resource-rich countries. We use two econometric approaches to investigate how international reserves affect the composition of equity capital investment to developing countries - static and dynamic panel data regressions.

\subsection{Static panel data approach}

Since we have cross-country time series data, we first consider the commonly used static fixed effects panel data regression ${ }^{11}$. We estimate the following equation,

\footnotetext{
${ }^{10}$ As shown in Appendix D, international reserves increase the level of both PEI and FDI. However, such effect is substantially higher for PEI than for FDI.

${ }^{11}$ The Hausman test rejects a random effects regression.
} 


$$
\text { PEI_Share } \text { Sht }_{i, t}=\alpha \cdot X_{i, t-1}+\beta \cdot Y_{i, t-1}+\gamma \cdot Z_{i, t-1}+\varepsilon_{i, t}
$$

where the dependent variable, $P E I_{-}$Share $_{i, t}$, is the share of country i’s stock of foreign portfolio equity investment (PEI) in the stock of total foreign equity investment, defined as the sum of PEI and FDI. $i$ and $t$ are country and year indices, respectively. Data of PEI and FDI are both taken from the EWN II data set of Lane and Milesi-Ferretti (2007).

For the independent variables, we follow the pull and push factors approach (Calvo et al, 1993; Chuhan et al., 1996; Montiel and Reinhart, 1999), which distinguishes pull factors (e.g. domestic factors in the recipient country) and push factors (e.g. external or world factors). Thus, in the regression model we include pull and push factors for both FDI and PEI that have been identified as important determinants in the literature.

$X_{i, t}$ is a vector, which contains factors affecting PEI inflows to a developing country. Those factors include stock market capitalization, institutional quality (proxied by the index of corruption and law and order from ICRG; lower institutional quality means less efficiency of the equity transaction technology and more informational frictions), international reserves (the ratio of international reserves to GDP), and a push factor - the world factor (three-month US Treasury bill rate). ${ }^{12}$

$Y_{i, t}$ is a vector of FDI determinants including the endowment with natural resources (the share of oil and mineral exports in total exports), trade openness and institutional quality (the same definition as for PEI).

Finally, $Z_{i, t}$ contains common factors that may affect both PEI and FDI, such as the market size of a developing country (measured by nominal GDP, in log value) and the real

\footnotetext{
${ }^{12}$ See for example, Chuhan et al. (1998), Portes and Rey (2005), and Fernandez-Arias (1996).
} 
GDP growth rate. A time trending variable is also included in $Z_{i, t}$ to control for a possible trend in the time series. A detailed definition of each variable can be found in Appendix C. ${ }^{13}$ All independent variables are lagged by one period to cope with possible endogeneity and reverse causality. Given this specification, any change in reserves precedes changes in PEI and FDI and, hence, the finding of significant effects is evidence for Granger causality running from reserves to PEI over FDI. Since our dependent variable is constructed as the ratio of PEI to total foreign equity investment, which includes FDI, we expect factors that positively affect FDI to have a negative effect on the dependent variable. For instance, trade openness, which is meant to positively affect FDI (a high level of trade openness is associated with high FDI inflows.), is expected to negatively affect PEI over total foreign equity investment. Variables that positively affect PEI, in turn, are expected to have a positive impact on our dependent variable.

\subsubsection{Estimation based on the full sample}

The results of fixed effects panel data regressions are reported in Table 1 . We first consider the effect of fundamentals on the composition of foreign equity investment as our benchmark regression (Column 1). We then additionally control for crises (Column 2) and the impact of policy, namely a country's de jure openness of the capital account and stock market liberalization (Columns 3 and 4).

In our benchmark regression in Column 1 we find that international reserves scaled by GDP indeed enter with a strongly significant and positive coefficient, thus confirming our

\footnotetext{
${ }^{13}$ Exchange rate volatility has been experimented with as an additional exogenous variable in the regressions, but it does not yield significant results. Possible explanations include: 1) Observed past exchange rate volatility may be an inappropriate measure as investors are usually forward-looking; 2) many developing countries have fixed exchange rates and hence exchange rate volatility may not play a role; and 3) the effect of exchange rate volatility may be captured by our crisis dummy variables, which are defined by the presence of large devaluations. Including exchange rate volatility in the regression may induce multicollinearity in that it is associated with other variables such as real GDP growth, capital controls, and international reserves. We subsequently dropped exchange rate volatility from our regressions.
} 
hypothesis that higher international reserves increase the share of PEI in total foreign equity investment. As the result indicates, a 1\% increase in international reserves is associated with an increase of $0.15 \%$ in the share of PEI.

Other factors related to PEI, namely stock market capitalization and institutional quality, are also significantly positive - a larger domestic stock market and better domestic institutional quality increase the share of PEI. These findings are in line with other papers, e.g. Wei and Wu (2002). Strictly speaking, institutional quality affects both PEI and FDI. For PEI, better institutional quality represents less informational frictions and better transaction technology in the domestic stock market. Portes and Rey (2005) find that institutional quality is among the most important determinants of foreign portfolio equity flows to developing countries. On the FDI side, an environment characterized by better institutional quality, theoretically, attracts more FDI. However, this intuition does not garner consensus in empirical studies. For instance, Wheeler and Mody (1992) find no evidence for a significant relation between FDI and institutional quality. Further, Fernandez-Arias and Hausman (2001) indicate that a country with weaker institutions tends to attract less capital but more of it in the form of FDI. Our result is seemingly congruous with Fernandez-Arias and Hausman (2001). The world short-term interest negatively affects the share of PEI in developing countries. In principal, short-term capital such as PEI seeks high returns, hence tends to flow to markets where the return is high. When the world interest rate goes up, the PEI in developing countries may head back to the world market.

Regarding FDI factors, only trade openness shows up significantly - it reduces the share of PEI. Trade openness is positively associated with FDI, which is included in the denominator of our dependent variable. Thus, a higher degree of trade openness raises FDI and lowers the share of PEI in total foreign equity investment. The other FDI factor, the endowment with natural resources, has no significant impact on the share of PEI. 
GDP and the growth rate of real GDP may positively affect both PEI and FDI. While the market size of a developing country (GDP) is found to increase the share of PEI in a developing country, the effect of market potential, proxied by the real GDP growth rate, is insignificant.

There is a plethora of discussions about the experience of sudden outflows of shortterm capital during crises in developing countries. The literature argues that a crisis with selffulfilling mechanism can lead to a large-scale capital reversal even if there is no shock to economic fundamentals (Caballero and Krishnamurthy, 2001). FDI, in turn, seems to be consistent in both tranquil and crisis periods; in fact, a financial crisis may be associated with an outflow of foreign PEI and a simultaneous inflow of FDI (Krugman, 2000). Hence, we anticipate that financial crises affect PEI and FDI differently and could influence the composition of PEI and FDI.

Thus, we add a few crisis variables to examine our anticipation and the robustness of our estimation results. There are four crisis variables - all of them are constructed as dummy variables. The first one, denoted as Crisis, takes on the value 1 if the annual exchange rate depreciation of the local currency exceeds 15\% (Reinhart and Rogoff, 2010). The effect of a crisis in a developing economy on capital inflows may last longer than one year. To consider such persistency, our Crisis dummy also equals 1 in the successive two years after a crisis has occurred. In addition, a large-scale regional or global financial crisis usually imposes substantial contagion effects on countries outside the inflicted region or globally. We thus include three notorious financial crises, Mexico 1994, East Asia 1997, and the global financial crisis of 2008, to address possible contagion. These three variables are set to 1 in the crisis year and all following years and equal 0 before the crisis materialized. For instance, the 
crisis variable of the global financial crisis in 2008 is set to 1 from 2008 to 2010 and equals 0 before the year $2008 .^{14}$

Column (2) reports the results of the regression including all four crisis variables. Adding four crisis dummy variable increases the overall explanatory power of our regression model as the R squared rises from $12 \%$ to $16 \%$. This shows the importance of crisis events for the composition of foreign equity investment in developing countries. With the exception of crises identified at the country level (the Crisis variable), all three crises significantly affect the share of PEI.

In line with the existing crisis literature, the 1997 East Asian financial crisis and the 2008 global financial crisis are found to reduce the share of PEI. They seem to deter PEI investors or get investors to switch from PEI to more stable and crisis resilient FDI. In addition, our result suggests that the impact of the 2008 global financial crisis is almost twice as large as that of the 1997 Asian financial crisis. The finding for the Mexican crisis of 1994, however, is quite contrasting. After the Mexican crisis, investors shore up more PEI compared to FDI. There are perhaps two reasons: First, the Mexican crisis was rather triggered by external debt than foreign equity investment; second, it coincided with the tide of capital account liberalization, which took place in the early 1990s in many developing countries. This policy change facilitated foreigners to hold PEI in developing countries (Bekaert, Harvey, and Lundblad, 2005).

Adding these four crisis variables does not significantly alter our results compared to the benchmark regression in Column (1). Although slightly reduced in value, the coefficient of international reserves is still positive and significant. The main difference is that

\footnotetext{
${ }^{14}$ To test the robustness of our results, we also use an alternative definition of global crises, where the dummy variable takes on the value one in years where the GDP growth rate is lower than in adjacent years. Our results with respect to the impact of international reserves are robust to this variation. Results may be obtained from the authors upon request.
} 
institutional quality becomes insignificant, its effect is positive in both specifications nonetheless.

In principle, the government's capital account policies, e.g. capital controls, in the recipient country have a direct effect on both the volume (Malaysia’s capital controls right after the 1997 financial crisis) and the composition of capital inflows (Chilean type of capital controls). Montiel and Reinhart (1999) present evidence that capital controls influence the composition of capital flows, but not their volume. Hence, when we study the composition of capital flows, ignoring the effect of capital controls could lead to omitted variable bias.

Thus, we add a capital control variable to the regression. Ideally, we need information on capital controls that distinguishes between controls on short-term and long-term capital inflows. ${ }^{15}$ However, since a large variety of capital controls has been proposed and implemented in different countries, an accurate empirical measure for capital controls appears to be a challenge. ${ }^{16}$ We rely on a commonly used de jure measure for capital account restrictions - the Chinn-Ito index - as the proxy to control for the effect of capital controls.

The results are presented in Column (3) of Table 1. They suggest that capital controls, albeit the estimated coefficient is positive (fewer capital controls imply a higher share of PEI), do not have a significant effect on the composition of foreign equity investment. Lack of better measures for capital control may lead to this insignificant estimate. As before, including the capital control variable does not change the estimate of other variables substantially. It marginally increases the R squared of our regression model.

In addition to capital controls, further capital account policies, particularly the liberalization of domestic equity markets, may substantially influence foreign investment in developing countries. For instance, Levin and Zervos (1998) find that the liberalization of

\footnotetext{
${ }^{15}$ There are varieties of capital controls, some target short-term capital inflows, some aim at the outflow, and some are imposed on long-term capital flows (See International Monetary Fund, Annual Report on Exchange Arrangements and Exchange Restrictions (AREAER) for more details).

${ }^{16}$ See for example, Magud et al. (2011) for a discussion of issues related to research on capital controls.
} 
restrictions on capital and dividend flows leads to larger stock markets and better stock market development. Henry (2000) finds in a sample of 11 emerging markets that the growth rate of investment is higher after equity market liberalization. Thus, we incorporate a measure for equity market liberalization in the regression (see Column (4) $)^{17}$. Indeed, we find that stock market liberalization in developing countries significantly increases the share of PEI. The results with respect to the other control variables are robust to the inclusion of stock market liberalization. Particularly, the coefficient of international reserves increases and becomes more significant. The overall R squared of the regression also rises to $28 \%$. However, we reserve caution in interpreting these results due to two reasons. First, the stock market liberalization data have limited country coverage, reducing our sample to 48 countries. Second, the original stock market liberalization data span from 1980 to 2005. To be compatible with our data, we extend the original data set of Bekaert, Harvey, and Lundblad (2005) by simply filling the observations after 2005 with the values of 2005.

To account for a richer dynamic relationship between reserves and foreign equity capital investment, we run regressions that include further lagged levels of international reserves (up to four lags). All variables lagged by more than one year do not significantly affect the ratio of PEI to FDI. In line with our previous results, only reserves lagged by one year significantly increase the ratio of PEI to FDI.

While our main analysis focuses on the composition of foreign equity investment, it might also be informative to study the effect of international reserves on the level of PEI and FDI individually. We run regressions where the dependent variable is the level of FDI and PEI, respectively, and report the results in Appendix D. A comparison of the coefficients of international reserves allows the following conclusions: (1) International reserves positively affect both PEI and FDI and (2) the positive effect of PEI is substantially higher than that of

\footnotetext{
${ }^{17}$ The data for equity market liberalization are taken from Bekaert, Harvey, and Lundblad (2005).
} 
FDI, averaged across the four specifications it amounts to 0.21 for PEI versus 0.10 for FDI.

To sum up, for a sample of 76 developing economies, we can empirically confirm our hypothesis derived from the theory in Section 2. The results are robust to the inclusion of additional control variables, e.g. financial crises, capital controls, and stock market liberalization.

\subsubsection{Estimation based on samples of natural resource-rich and non-resource countries}

Natural resource-rich countries may have different foreign equity investment positions than non-natural resource developing countries. In general, natural resource-seeking FDI is the predominant type of foreign equity investment in resource-rich countries. Those FDIs are important for developing countries rich in natural resources as they entail management skills and technologies that are vital to the development of industries exploiting and processing natural resources. In addition, FDIs may help resource-rich countries to survive extreme commodity market conditions like low commodity prices and sanctions. Indeed, foreign-owned companies are described as the backbone of the oil industry in many oil-producing countries (Fattouch, 2008).

In contrast, PEI in resource-rich developing countries is much weaker. Shallow domestic financial markets and poor institutional quality constrain the development of stock markets. They discourage foreign investors from engaging in the domestic stock market. In addition, Dutch disease (natural resource industry suffocates the development of other industries, e.g. manufacturing) and volatile boom-bust business cycles, which are closely linked to the volatility of commodity prices, deter PEI investment. In fact, Billimerie and Massa (2007) find that the main driver of stock market development in natural resource-rich developing countries is the commodity price. As a result, natural resource-seeking FDI 
usually is the dominant type of foreign equity investment to natural resource countries (Figure 3).

Central banks’ international reserves in natural resource-rich countries have soared since 2000 when their revenues from natural resources jumped due to the commodity price boom (Figure 4). However, the primary motive for accumulating international reserves are precautionary savings: Reserves can be used to buffer income shocks, to smooth intertemporal consumption, and to ensure intergenerational equity since natural resources are exhaustible (Cherif and Hasanov, 2012; IMF, 2012 ).

Against this backdrop, we expect that the effect of international reserves on the composition of foreign equity investment differs between resource-rich and non-resource developing economies. To empirically test this hypothesis, we split our country sample into two sub-samples: a sample of 20 natural resource-rich countries ${ }^{18}$, whose natural resource (both oil and minerals) exports account for more than $40 \%$ of their total merchandise exports, and a sample of 56 non-natural resource developing countries.

We repeat the regression procedure as explained in Section 3.1.1 for these two samples. All variables are the same as in Section 3.1.1, except that we include a "crude oil price” variable, a proxy for commodity prices. The oil price is identified to be an important factor promoting the development of stock markets in resource-rich countries (Cherif and Hasanov, 2012). A better developed stock market, in turn, is expected to attract foreign portfolio investment, everything else equal. The results are reported in Tables 2 and 3, respectively.

As expected, in our sample of 20 natural resource-rich countries international reserves have no significant impact on the share of PEI. The variation in the share of PEI is

\footnotetext{
${ }^{18}$ We include 20 natural resource rich developing countries in our regression analysis. They are Azerbaijan, Bahrain, Bolivia, Chile, Ecuador, Egypt, Indonesia, Kazakhstan, Kuwait, Mongolia, Nigeria, Oman, Papua New Guinea, Peru, Qatar, Russia, Saudi Arabia, United Arab Emirates, Venezuela, and Zambia. Due to data availability, most African natural resource-rich countries are excluded from our sample.
} 
mostly explained by stock market capitalization and the global financial crisis of 2008-10 (Columns 2 and 3). An increase in the stock market size by 1\% increases the share of PEI by more than $1 \% .{ }^{19}$ The global financial crisis of 2008-10 significantly decreases the PEI share, which indicates that the usual behavior of short-term capital - a sudden stop or capital reversal during turbulent periods - applies to natural resource-rich countries as well. The result in Column (4) suggests that, within the limited scope of our sample (10 resources-rich countries), stock market liberalization is more important than stock market capitalization in affecting the composition of foreign equity investment. As our results show stock market capitalization becomes insignificant when stock market liberalization is controlled for. In contrast to our expectation, the price of crude oil does not affect the composition of foreign equity investment. A plausible explanation is that a higher oil price might drive up both PEI and FDI to natural resource-rich countries.

For the sample of non-resource countries, whose results are presented in Table 3, most variables garner similar estimates as in Table 1. International reserves have the same significance while the estimated coefficient increases from about 1.2 in the full sample to more than 1.6 in the non-resource country sample. The stock market capitalization and the market size (GDP) are other two important factors that positively affect the share of PEI. A high world interest rate withdraws PEI from developing countries. Better institutional quality is found to increase the share of PEI in two out of four regressions. While the Mexican crisis is positively associated with the share of PEI, the other two large-scale crises, the Asian crisis of 1997 and the global crisis of 2008, reduce the share of PEI. As in Table 1, while capital controls are estimated to be insignificant, stock market liberalization is found to increase the share of PEI in a sample of 38 countries.

\footnotetext{
${ }^{19}$ Alternatively, we included the stock market trading turnover instead of stock market capitalization in the regression. Results do not differ.
} 
Overall, our results are reasonable and robust to different data samples. We proceed by examining a different empirical specification to check the robustness of our findings.

\subsection{Dynamic panel data approach}

In this section, we use a dynamic panel data regression to further study how international reserves affect the composition of foreign equity investment.

In essence, the static panel data model specification in Section 3.1 is based on a partial equilibrium model. That is, it examines the determinants of the share of PEI in equilibrium. However, the foreign investment composition may deviate from its “equilibrium” value if the adjustment process is gradual (Faria et al., 2007).

To accommodate such a gradual process, we follow the partial stock adjustment model of Chow (1967),

$$
y_{i, t}=(1-\rho) \cdot y_{i, t-1}+\rho \cdot y_{i, t}^{*}
$$

where $y_{i, t}$ is the actual capital position and $y_{i, t}^{*}$ is the "equilibrium" capital position, both determined in period $t ;(1-\rho)$ indicates the speed of adjustment.

We can apply the above reasoning to our model by specifying a dynamic panel data generating process as the following,

$$
P E I_{-} \text {Share }_{i, t}=\theta \cdot P E I_{-} \text {Share }_{i, t-1}+\alpha \cdot X_{i, t-1}+\beta \cdot Y_{i, t-1}+\gamma \cdot Z_{i, t-1}+\varepsilon_{i, t}
$$

where we basically augment equation (3) with a lagged dependent variable to form a dynamic panel data regression.

When a lagged dependent variable is included in the estimation, the panel data OLS regression is biased and inconsistent (Anderson and Hsiao, 1981). A commonly used 
alternative approach, provided by Arellano and Bond (1991), Arellano and Bover (1995), and Blundell and Bond (1998) is the System Generalized Method of Moments (GMM) estimator, which provides unbiased and consistent estimates in a dynamic panel data environment.

The System GMM estimator is designed to deal with issues that arise in a linear functional relation, for example, 1) the dependent variable is dynamic and depends on its own past realization; 2) heteroskedasticity and autocorrelation; and 3) independent variables that are not strictly exogenous - either correlated with the error term or subject to reverse causality. As we have to address these problems in our empirical exercise, the System GMM is appealing for our study.

Although System GMM provides many advantages, it is complicated to implement and can easily generate invalid estimates. To cope with the complexity, the key is to obtain proper instruments, to guarantee the overall validity of the moment conditions, and to control for serial correlation in the error term of the equation in levels. We employ the Hansen Test (Hansen, 1982) to check for the overall validity of the selected moment conditions and use the Arellano and Bond (1991) Test to check for possible serial correlation in the level equation.

In addition, there is a specific issue associated with our exercise when using the System GMM. That is, the long time dimension of our data set (1980-2010) may cause too many instruments, which potentially makes the two-step System GMM almost useless for inference (Arellano and Bond, 1991). To deal with this issue we use one-step System-GMM instead, which is theoretically less efficient than the two-step counterpart. However, according to Windmeijer's (2005) test, the difference between both is only marginal.

Table 4 present the results of estimating equation (4) on the full sample. The estimate for the lagged dependent variable is highly significant across all four regressions. The results 
thus confirm that the composition of foreign equity investment adjusts gradually to its equilibrium. The speed of adjustment is fairly quick, about 50\% per annum.

Our main hypothesis is also confirmed in this dynamic specification. The value of the coefficient of international reserves has tripled compared to the results of Table 1. It suggests that international reserves have a greater impact on the share of PEI once the dynamic adjustment process is controlled for. When we examine our hypothesis in the limited sample (48 countries) with the stock market liberalization variable added (Column 4), the international reserve estimate is marginally insignificant ( $p$ value is about 0.11 ). Stock market liberalization itself is not significant.

The other estimates are comparable to those of Table 1, but with some alterations. GDP, the world interest rate, and all three financial crises affect the share of PEI in an intuitive way. Two PEI pull factors, stock market capitalization and institutional quality, become insignificant. Two pull factors of FDI, trade openness and the endowment with natural resources, change signs compared to Table 1 - a larger endowment with natural resources significantly reduces the share of PEI; this might be explained by the fact that natural resource endowment attracts more FDI relative to PEI. Less restrictive capital controls are estimated to increase the share of PEI (Column 3), which is intuitive as well. Interestingly, in contrast to Table 1, the Mexican financial crisis enters with a significantly negative sign now. Recall that, in Table 1 where we did not control for the possibly gradual adjustment of the equity investment position, we found that the Mexican financial crisis of 1994 changed the composition of foreign equity investment in favor of PEI. It seems that once we control for the adjustment process of the investment position, the Mexican crisis plays the traditional role as other crises do and reduces the share of short-term capital, namely PEI. 
In natural resource-producing countries (Table 5), the only real factor that affects the share of PEI seems to be economic growth - the share of PEI rises with the rate of economic growth. The lagged dependent variable is significant and the speed of adjustment, which amounts to $70 \%$ per year, is faster than in the full sample. Three large scale crises significantly reduce the share of PEI. In contrast to the results for the static specification, stock market capitalization is insignificant. When we add the stock market liberalization variable in the regression (Column 4), the market size (GDP) becomes significant and positively affects the share of PEI. Trade openness now is positive and institutional quality negative, both in contrast to our expectation.

The results for the sample of non-resource developing countries (see Table 6) replicate those obtained with a static specification. However, the dynamic adjustment is one of the key factors explaining the variation of the share of PEI. International reserves also exert a positive and substantial pull effect on the share of PEI, the magnitude of which is more than twice as large compared to the estimates in Table 3. Capital controls are now significant. As expected, in the presence of weaker constraints on cross-border capital movements, the share of PEI in total foreign equity investment rises. The effect of the Mexican Crisis of 1994 takes on the expected negative sign, while stock market liberalization does not significantly affect the share of PEI in the dynamic environment.

We conclude for the dynamic specification that, although the adjustment process to equilibrium has substantial explanatory power and may have disturbed some of our results discussed in Section 3.1, most of our results are robust and in line with intuition. Particularly, we can confirm that the positive effect of international reserves on the share of PEI is consistent across static and dynamic model specifications. 


\section{Implications of the composition of foreign equity investment}

Understanding the pros and cons of PEI and FDI and the effect that international reserves impose on the composition of equity capital investment is pivotal for policy makers who aim at making proper adjustments to international reserve holdings in order to extract most benefits out of both PEI and FDI.

In contrast to international debt flows, whose fixed interest rate is independent of the return earned in the investment project, FDI and PEI are forms of risk sharing between domestic borrowers and foreign creditors. They confer part of the risk on foreign creditors since their returns are cyclical. ${ }^{20}$ This feature makes them more attractive for borrowers.

The main difference between FDI and PEI is that the first is considered as a long-run commitment, whereas the latter may be purely part of the optimal portfolio allocation of a foreign investor. FDI investors show interest in the economic activities of the firm and assume managerial rights.

Thanks to the transfer of technological know-how and managerial practices FDI offers greater positive externalities than PEI. PEI, in turn, is more liquid than FDI since it may be sold at the stock market at any time. FDI is more costly to reverse because of high transaction costs or a low recovery value.

In comparison to PEI and debt investment, FDI is less affected by asymmetric information because investors participate in the management of the project and because they have access to insider information. This might be a reason why PEI projects are managed less efficiently than FDI projects (see Goldstein and Razin, 2006).

This information asymmetry between domestic and foreign investors might result in a lemons type problem: Since foreign investors observe average firm productivity (domestic investors observe firm-specific productivities), high productivity firms will be purchased by

\footnotetext{
${ }^{20}$ Returns are higher if the project is successful and returns are depressed if the project turns out to be an economic failure.
} 
domestic agents and only shares of low-productivity firms are offered to foreign investors. Knowing this, foreign investors equity purchases are below an efficient level. Gordon and Bovenberg (1996) and Razin et al. (1998) propose that a subsidy to foreign equity investment may correct this market failure. Central banks’ international reserves are an indirect way of subsidizing foreign investors and may alleviate this market failure.

Figure 2 shows that the ratio of PEI to FDI is relatively low in developing countries compared to industrialized countries. This might indicate that the level of PEI is below its efficient level in emerging markets. As shown in our theoretical and empirical analysis, reserve hoardings might contribute to an increase of PEI relative to FDI.

The benefits from an increase in cross-border equity holdings might be substantial (see Rogoff, 1999): Equity trades allow small countries whose production depends on a small number of goods to diversify their income risk. Moreover, equity facilitates investment in riskier but high-yielding projects. Additional benefits of international equity flows might be indirect: Portfolio equity flows may be conducive to the development of domestic stock markets (Lane and Milesi-Ferretti, 2000). Stock market development, in turn, promotes the development of the domestic banking system (Demirgüc-Kunt and Levine, 1996).

\section{Concluding remarks}

We use an illustrative theoretical model to demonstrate that international reserves, via the channel of stabilizing the exchange rate, reduce the risk premium of PEI and, by implication, help to attract a higher share of PEI in total equity capital investment.

In our empirical investigation, we confirm that a higher level of international reserves is associated with a higher share of PEI in total foreign equity investment. Some push and pull factors, including stock market capitalization, institutional quality, the world long-term interest rate and trade openness are also found to significantly affect the composition of 
foreign equity investment. Large scale regional and global financial crises reduce the share of short-term equity investment, namely PEI.

Interestingly, we do find little evidence that capital controls influence the share of PEI. This might be attributed to the fact that the effectiveness of capital controls is not adequately accounted for by existing measures of de jure capital mobility.

Given that natural resource-producing countries may have a special industry structure in which FDI plays a vital role, we postulate that the composition of foreign equity investment (e.g. the share of PEI) may be different from non-resource countries. As a corollary, the effect of international reserves on the PEI share in total foreign equity investment may differ as well. Our empirical analyses on natural resource and non-resource country samples confirm our postulation. While international reserves significantly raise the share of PEI in total foreign equity investment in non-resource countries, we find no evidence that international reserves play a role for the composition of foreign equity investment in natural resource-rich countries.

With respect to crises we confirm that the share of PEI falls as a response to financial turmoil. Our findings for the global financial crisis beginning in 2008 are illustrative: The effect has been much stronger than in previous crises (Mexican and East Asian crises) and is especially strong in developing countries that are not major resource exporters. A high level of reserves has allowed countries to limit the outflow of PEI.

Our results may also imply that central banks’ reserves offer collateral benefits: By attracting PEI, they contribute to the development of domestic financial markets and facilitate domestic firms’ access to external financial resources. Because financial markets in developing countries tend to be dominated by the banking system, a better developed domestic stock market may contribute to a more balanced distribution of capital flows across the financial system. Moreover, if PEI replaces portfolio debt financing, it allows investors to 
share risk with their creditors (Faria et al, 2007). Thereby, reserves may help to shift the composition of foreign equity capital in developing country markets to levels observed in industrial countries (see Figure 2).

These findings, however, also reveal a possible dilemma: Central banks’ intention to reduce crisis vulnerability by the accumulation of a large stock of reserves might partly be offset by the endogenous response of market participants: Reserves tilt the composition of flows towards PEI, which can easily be reversed and cause a stock market crisis as shown by Eichler and Maltritz (2011a, 2011b). 


\section{Appendix A: Foreign equity investment - growth versus crises}

In order to gauge the economic impact of different types of capital flows this appendix provides a non-exhaustive literature review of the effects of different types of capital inflows on economic growth and crisis incidence.

Growth

The composition of capital flow matters because they may affect economic growth. Borensztein et al. (1998) find a positive growth effect of FDI. First, FDI gives developing countries access to advanced technologies. Second, FDI positively affects domestic investment (crowding-in effect).

Bekaert and Harvey (2000) demonstrate that private equity flows from the US positively affect emerging markets' growth. Durham (2003), in contrast, reports an insignificant effect of the sum of FDI and PEI on growth.

Aizenman ans Sushko (2011a) investigate the growth effects of different types of capital flows: While FDI inflows are found to enhance growth, overall PEI inflows are negatively associated with growth. In a restricted sample of financially-constrained firms, however, PEI inflows increase growth.

In a related paper (Aizenman and Sushko, 2011b) the authors investigate the effect of capital inflow types on the probability of economic takeoffs, defined as a five year period of sustained growth. Both short-term debt and portfolio equity flows reduce the probability of a takeoff.

\section{Crises}

Joyce (2011) finds that foreign debt liabilities increase the probability of a banking crisis, whereas portfolio flows - FDI and PEI - make a crisis less likely to happen. Levchenko and Mauro (2007) report that both FDI and PEI play no role around sudden stop episodes.

Tong and Wei (2010) study whether the credit crunch during the financial crisis of 2008-10 depends on the pre-crisis composition of capital flows. The credit crunch is found to be more severe for firms that relied more on non-FDI capital flows. The decline of stock prices was stronger for firms that were more dependent on external sources of financing.

\section{Appendix B: Reserves and the composition foreign equity investment: theory}

In principal, international reserves affect both PEI and FDI. However, the evidence suggests that international reserves affect FDI less than PEI (see Appendix D). Thus, for simplicity, we treat FDI as the benchmark investment in developing countries and assume that the return of FDI in a developing country equals the world risk-free return, $r^{f}$ plus a country-specific risk premium, $\rho$ (see Equation 1). Hence in our benchmark specification, the 
stock of FDI in developing countries is not affected by changes in international reserves ${ }^{21}$, that is

$$
\frac{\partial F D I}{\partial I R}=0
$$

where FDI denotes the stock of FDI and IR the stock of international reserves. The effect of reserves on the stock of portfolio equity investment, denoted by PEI, works via a reduction in the risk premium of PEI, that is

$$
\frac{\partial P E I}{\partial I R}=\frac{\partial P E I}{\partial R P} \cdot \frac{\partial R P}{\partial I R}
$$

which can be expressed as follows:

$$
\frac{\partial P E I}{\partial I R}=\frac{p_{I R}(1-q)-p q_{I R}}{p-p q} \cdot \eta \cdot P E I
$$

where $\eta$ is the elasticity of the stock of PEI with respect to the risk premium. This shows that the effect of reserve changes on the stock of PEI is a positive function of the level of PEI and of the effect of the risk premium on the stock of PEI. Combining (B1) and (B2) gives us the expression for the effect of reserve changes on the composition of foreign equity investment:

$$
\frac{\partial\left(\frac{P E I}{F D I}\right)}{\partial I R}=\frac{1}{F D I} \cdot \frac{\partial P E I}{\partial I R}=\frac{p_{I R}(1-q)-p q_{I R}}{p-p q} \cdot \eta \cdot \frac{P E I}{F D I}
$$

It suggests that international reserves have a positive effect on the ratio of PEI to FDI. This effect is determined by the existing ratio of PEI to FDI, $\eta$, the effect of reserves on the crisis probability, and the effect of reserves on the recovery ratio.

Since our model is silent about the numerical value of these individual effects, we cannot measure the magnitude of the effect. Estimates of the effects might be provided by a calibration analysis, which, however, is beyond the scope of this paper. Our model is primarily intended to provide theoretical guidance with respect to the sign of the expected effects.

\footnotetext{
${ }^{21}$ Alternatively, the effect of IR on FDI might be modeled in the same fashion as equation (B2), where the effect is multiplied by an impact coefficient $\theta<1$ to account for the weaker effect of IR on FDI.
} 


\section{Appendix C: Variable Definitions}

PEI

FDI

$G D P$

Real GDP growth

Trade Openness

Natural resources

Stock market capitalization

Institutional quality

International reserves

World short-term interest rate

Capital controls

Stock market liberalization

Crisis

Mexican crisis 1994

East Asian crisis 1997

Oil price

Trend
Stock data of portfolio equity investment in million USD. [Source: Lane and Milesi-Ferretti (2007) EWN II data set]

FDI stock data in million USD. [Source: Lane and Milesi-Ferretti (2007) EWN II data set]

The host country's GDP in current USD. [Source: World Bank, World Development Indicators]

The host country's real GDP growth rate. [Source: World Bank, World Development Indicators]

The host country's trade openness, calculated as total trade scaled by the GDP. [Source: World Bank, World Development Indicators]

The host country's output of natural resources, calculated as total output of oil and mineral scaled by GNI. [Source: World Bank, World Development Indicators]

The host country’s stock market capitalization over GDP. [Source: World Bank, World Development Indicators]

Index of institutional quality, measured as the sum of the index of corruption and the index of law and order. [Source:ICRG]

International reserves minus gold over GDP. [Source: World Bank, World Development Indicators]

World short-term interest rate, measured by the US 3-month T-bill rate. [Source: the US Treasury Department]

Measure for capital controls, using Chinn-Ito index (Chinn and Ito, 2006). A higher index value indicates less restriction and more capital account openness in a developing country.

Measure for domestic stock market liberalization in a developing country. Ratio of domestic stocks available to foreign investors. Calculated as the share of IFC investable in total stock market capitalization. [Source: Bekaert, Harvey, and Lundblad (2005)]

Dummy variable for currency crises. Equals one if the annual depreciation rate of the domestic currency relative to the dollar or other anchor currencies equals 15\% or more (see Reinhart and Rogoff, 2010).

Dummy variable for the 1994 Mexican crisis, $\mathrm{I}(\mathrm{t}>94)=1$, otherwise 0 .

Dummy variable for the 1997 Asian financial crisis, $\mathrm{I}(\mathrm{t}>97)=1$, otherwise 0 .

The spot price of crude oil, dollars per barrel. [Source: the US Energy Information Administration]

A time trending variable. 


\section{Appendix D: International reserves' effect on the level of PEI and FDI}

Table D1: Panel data regression with the stock of PEI (relative to GDP) as dependent variable

\begin{tabular}{|c|c|c|c|c|}
\hline & (1) & (2) & (3) & (4) \\
\hline International reserves(-1) & $\begin{array}{c}0.247 * * * \\
(0.05)\end{array}$ & $\begin{array}{c}0.228 * * * \\
(0.06)\end{array}$ & $\begin{array}{c}0.201 * * * \\
(0.06)\end{array}$ & $\begin{array}{c}0.167 * * * \\
(0.06)\end{array}$ \\
\hline Stock market capitalization(-1) & $\begin{array}{c}0.347 * * * \\
(0.09)\end{array}$ & $\begin{array}{c}0.350 * * * \\
(0.10)\end{array}$ & $\begin{array}{c}0.343^{* * *} \\
(0.10)\end{array}$ & $\begin{array}{c}0.367 * * * \\
(0.09)\end{array}$ \\
\hline Institutional quality(-1) & $\begin{array}{c}0.053^{* * *} \\
(0.02)\end{array}$ & $\begin{array}{l}0.030 \\
(0.02)\end{array}$ & $\begin{array}{l}0.026 \\
(0.02)\end{array}$ & $\begin{array}{l}0.016 \\
(0.02)\end{array}$ \\
\hline GDP $(-1)$ & $\begin{array}{l}-0.061 \\
(0.12)\end{array}$ & $\begin{array}{l}0.174 \\
(0.14)\end{array}$ & $\begin{array}{c}0.242 * \\
(0.14)\end{array}$ & $\begin{array}{c}0.335 * * \\
(0.15)\end{array}$ \\
\hline Real GDP growth(-1) & $\begin{array}{c}2.416^{* * *} \\
(0.74)\end{array}$ & $\begin{array}{c}2.528 * * * \\
(0.77)\end{array}$ & $\begin{array}{c}2.119 * * * \\
\quad(0.80)\end{array}$ & $\begin{array}{c}2.336 * * * \\
(0.76)\end{array}$ \\
\hline World short-term interest rate(-1) & $\begin{array}{c}-0.040 * * \\
(0.02)\end{array}$ & $\begin{array}{l}-0.030 \\
(0.02)\end{array}$ & $\begin{array}{c}-0.036^{*} \\
(0.02)\end{array}$ & $\begin{array}{c}-0.057 * * * \\
(0.02)\end{array}$ \\
\hline Crises & & $\begin{array}{l}-0.026 \\
(0.14)\end{array}$ & $\begin{array}{l}-0.004 \\
(0.14)\end{array}$ & $\begin{array}{l}0.010 \\
(0.15)\end{array}$ \\
\hline Mexican crisis 1994 & & $\begin{array}{l}0.113 \\
(0.12)\end{array}$ & $\begin{array}{l}0.105 \\
(0.12)\end{array}$ & $\begin{array}{l}0.147 \\
(0.12)\end{array}$ \\
\hline East Asian crisis 1997 & & $\begin{array}{c}-0.212^{*} \\
(0.11)\end{array}$ & $\begin{array}{c}-0.235^{* *} \\
(0.12)\end{array}$ & $\begin{array}{c}-0.104 \\
(0.11)\end{array}$ \\
\hline Global Financial Crisis 2008 & & $\begin{array}{c}-0.740^{* * *} \\
(0.14)\end{array}$ & $\begin{array}{c}-0.740 * * * \\
(0.14)\end{array}$ & $\begin{array}{c}-0.966 * * * \\
(0.19)\end{array}$ \\
\hline Capital controls(-1) & & & $\begin{array}{l}0.043 \\
(0.06)\end{array}$ & $\begin{array}{l}0.059 \\
(0.06)\end{array}$ \\
\hline Stock market liberalization(-1) & & & & $\begin{array}{c}1.298 * * * \\
(0.14)\end{array}$ \\
\hline Trend & $\begin{array}{c}0.098 * * * \\
(0.01)\end{array}$ & $\begin{array}{c}0.118^{* * *} \\
(0.02)\end{array}$ & $\begin{array}{c}0.114^{* * *} \\
(0.02)\end{array}$ & $\begin{array}{c}0.044^{* *} \\
(0.02)\end{array}$ \\
\hline Constant & $\begin{array}{c}-4.443^{*} \\
(2.62)\end{array}$ & $\begin{array}{c}-10.457 * * * \\
(3.21)\end{array}$ & $\begin{array}{c}-12.026^{* * *} \\
(3.24)\end{array}$ & $\begin{array}{c}-13.323^{* * *} \\
(3.41)\end{array}$ \\
\hline Adjusted R-squared & 0.44 & 0.46 & 0.45 & 0.55 \\
\hline Observations & 1051 & 924 & 910 & 689 \\
\hline Number of countries & 70 & 70 & 70 & 48 \\
\hline
\end{tabular}

Note: The table reports the results of estimating equation (3) with a static panel data fixed-effects regression. Robust errors are in parentheses underneath coefficient estimates. “***, **, *” indicate 1\%, $5 \%$, and $10 \%$ level of significance, respectively. The dependent variable is the logarithm of the stock of PEI relative to GDP. 
Table D2: Panel data regression with the stock of FDI (relative to GDP) as dependent variable

(1)

International reserves(-1)

Institutional quality(-1)

Natural resources(-1)

Trade openness(-1)

World short-term interest rate(-1)

GDP(-1)

Real GDP growth(-1)

Crisis

Mexican crisis 1994

East Asian crisis 1997

Global Financial Crisis 2008

Capital controls(-1)

Stock market liberalization(-1)

Trend

Constant

Adjusted R-squared

Observations

Number of countries
(2)

(3)

(4)

\begin{tabular}{|c|c|c|c|}
\hline $\begin{array}{c}0.062 * * * \\
(0.02)\end{array}$ & $\begin{array}{c}0.061 * * * \\
(0.02)\end{array}$ & $\begin{array}{c}0.059 * * * \\
(0.02)\end{array}$ & $\begin{array}{c}0.140 * * * \\
(0.03)\end{array}$ \\
\hline $0.035 * * *$ & $0.038 * * *$ & $0.033^{* * *}$ & 0.004 \\
\hline$(0.01)$ & $(0.01)$ & $(0.01)$ & $(0.01)$ \\
\hline $0.342 * * *$ & $0.359 * * *$ & $0.358 * * *$ & $0.395^{*}$ \\
\hline$(0.11)$ & $(0.12)$ & $(0.12)$ & $(0.21)$ \\
\hline $0.004^{* * *}$ & $0.004^{* * *}$ & $0.004^{* * *}$ & $0.003^{* * *}$ \\
\hline$(0.00)$ & $(0.00)$ & $(0.00)$ & $(0.00)$ \\
\hline 0.002 & 0.000 & -0.001 & 0.001 \\
\hline$(0.01)$ & $(0.01)$ & $(0.01)$ & $(0.01)$ \\
\hline$-0.154 * * *$ & $-0.093 *$ & $-0.096^{*}$ & -0.059 \\
\hline$(0.04)$ & $(0.05)$ & $(0.05)$ & $(0.07)$ \\
\hline 0.085 & 0.133 & 0.010 & $1.072 * * *$ \\
\hline \multirow[t]{13}{*}{$(0.27)$} & $(0.27)$ & $(0.28)$ & $(0.36)$ \\
\hline & $0.112^{*}$ & 0.094 & $0.190 * *$ \\
\hline & $(0.06)$ & $(0.06)$ & (0.09) \\
\hline & -0.061 & -0.041 & 0.031 \\
\hline & $(0.05)$ & $(0.05)$ & $(0.06)$ \\
\hline & $0.296 * * *$ & $0.268 * * *$ & $0.272^{* * *}$ \\
\hline & $(0.05)$ & $(0.05)$ & $(0.06)$ \\
\hline & -0.092 & -0.086 & -0.152 \\
\hline & $(0.06)$ & $(0.06)$ & $(0.11)$ \\
\hline & & -0.027 & 0.012 \\
\hline & & $(0.03)$ & $(0.03)$ \\
\hline & & & $0.411^{* * *}$ \\
\hline & & & $(0.07)$ \\
\hline $0.073 * * *$ & $0.054 * * *$ & $0.055 * * *$ & $0.038 * * *$ \\
\hline$(0.00)$ & $(0.01)$ & $(0.01)$ & $(0.01)$ \\
\hline-0.019 & -1.273 & -1.133 & -1.438 \\
\hline$(0.96)$ & (1.12) & (1.13) & (1.65) \\
\hline 0.55 & 0.54 & 0.53 & 0.63 \\
\hline 1822 & 1658 & 1641 & 868 \\
\hline 100 & 100 & 100 & 48 \\
\hline
\end{tabular}

Note: The table reports the results of estimating equation (3) with a static panel data fixed-effects regression. Robust errors are in parentheses underneath coefficient estimates. “***, **, *” indicate $1 \%$, $5 \%$, and $10 \%$ level of significance, respectively. The dependent variable is the logarithm of the stock of FDI relative to GDP. 


\section{References}

Acharya, Viral, Hyun Song Shin and Tanju Yorulmazer (2011), “Fire-sale FDI”, Princeton University, Working Paper.

Aguiar, Mark and Gita Gopinath (2005), "Fire-sale foreign direct investment and liquidity crises”, Review of Economics and Statistics 87(3): 439-452.

Aizenman, Joshua and Nancy Marion (2004), "International reserve holdings with sovereign risk and costly tax collection”, Economic Journal 114: 569-591.

Aizenman, Joshua and Nancy Marion (2002), "Reserve uncertainty and the supply of international credit”, Journal of Money, Credit and Banking, Vol. 34, No. 3: 631-649.

Aizenman, Joshua and Daniel Riera-Crichton (2008), "Real exchange rate and international reserves in an era of growing financial and trade integration”, Review of Economics and Statistics 90: 812-815.

Aizenman, Joshua and Vladyslav Sushko (2011a), “Capital flow types, external financing needs, and industrial growth: 99 countries, 1991-2007”, NBER Working Paper 17228.

Aizenman, Joshua and Vladyslav Sushko (2011b), "Capital flows: catalyst or hindrance to economic takeoffs?”, NBER Working Paper 17258.

Alfaro, Laura and Fabio Kanczuk (2009), “Debt maturity: Is long-term debt optimal?”, Review of International Economics 17, No. 5: 890-905.

Anderson, Theodore W. and Cheng Hsiao (1981), "Estimation of dynamic models with error components”, Journal of American Statistical Association, 76, 598-606.

Arellano, Manuel and Stephen Bond (1991), "Some tests of specification for panel data: Monte Carlo evidence and an application to employment equations”, Review of Economic Studies 58: 277-97.

Arellano, Manuel and Olympia Bover (1995), "Another look at the instrumental variables estimation of error components models,” Journal of Econometrics 68: 29 -51.

Bekaert, Geert and Campbell R. Harvey (2000), "Foreign speculators and emerging equity markets”, Journal of Finance 55: 565-613.

Bekaert, Geert, Campbell R. Harvey, Christian Lundblad (2005), "Does financial liberalization spur growth”, Journal of Financial Economics 77: 3-55.

Blundell, Richard and Stephen Bond (1998), "Initial conditions and moment restrictions in dynamic panel data models”, Journal of Econometrics Vol. 87, No.1: 115-143.

Borensztein, Eduardo, José de Gregorio and Jong-Wha Lee (1998), "How does foreign direct investment affect economic growth?”, Journal of International Economics 45: 115-135.

Burnside, Craig, Martin Eichenbaum and Sergio Rebelo (2001), "Hedging and financial fragility in fixed exchange rate regimes”, European Economic Review, Volume 45(7): 1151-1193.

Caballero Ricardo J. and Arvind Krishnamurthy (2001), "International and domestic collateral constraints in a model of emerging market crises”, Journal of Monetary Economics 48(3): 513-548.

Calvo, Guillermo, Leonardo Leiderman and Carmen Reinhart (1993), “Capital inflows and the real exchange rate appreciation in Latin America: the role of external factors”, IMF Staff Papers, Vol. 40(1): 108-151.

Cherif, Reda and Fuad Hasanov (2012), “Oil exporters’ dilemma: How much to save and how much to invest?” IMF Working Paper WP/12/4. 
Chinn, Menzie D. and Hiro Ito (2006), "What matters for financial development? Capital controls, institutions, and interactions”, Journal of Development Economics, Vol. 81(1): 163-192.

Chow, Gregory C. (1967), “Technological change and the demand for computers”, American Economic Review, 57, 1117 - 1130.

Chuhan, Punam, Stijn Claessens and Nlandu Mamingi (1998), "Equity and bond flows to Latin America and Asia: the role of global and country factors", Journal of Development Economics, Vol. 55 (April): 439-63.

Corsetti, Giancarlo, Paolo Pesenti and Nouriel Roubini (1999), "Paper tigers? A model of the Asian crisis”, European Economic Review 43: 1211-1236.

De Gregorio, José and Jong-Wha Lee (2004), "Growth and adjustment in East Asia and Latin America", Economía Vol. 5, No.1: 69-115.

Demirgüç-Kunt, Asli and Ross Levine (1996), "Stock market development and financial intermediaries: stylized facts”, World Bank Economic Review 10(2): 291-321.

Durham, J. Benson (2003), “Foreign portfolio investment, foreign bank lending, and economic growth”, Board of Governors of the Federal Reserve System, International Finance Discussion Papers No. 757.

Eichler, Stefan and Dominik Maltritz (2011a), "Stock market-induced currency crises - a new type of twins”, Review of Development Economics, 15(2): 223-236.

Eichler, Stefan and Dominik Maltritz (2011b), "Currency crises and the stock market: empirical evidence for another type of twin crisis”, Applied Economics, 43(29): 4561-4587.

Fama, Eugene F. (1981), “Stock returns, real activity, inflation, and money”, American Economic Review, Vol. 71(4): 545-565.

Faria, André, Philip Lane, Paolo Mauro, and Gian Maria Milesi-Ferretti (2007), “The shifting composition of external liabilities”, Journal of the European Economic Association, 5, 480-490.

Fernandez-Arias, Eduardo (1996), “The new wave of private capital inflows: push or pull?” Journal of Development Economics, Vol. 48: 382-418.

Fernández-Arias, Eduardo and Ricardo Hausmann (2001), "Is foreign direct investment a safer form of financing?”, Emerging Markets Review, Volume 2(1): 34-49.

Frankel, Jeffrey A. and George Saravelos (2012), "Are leading indicators of financial crises useful for assessing country vulnerability? Evidence from the 2008-09 global crisis", Journal of International Economics, Vol. 87, Issue 2: 216-231.

Glen, Jack (2002), “Devaluations and emerging stock market returns”, Emerging Markets Review 3(4): 409-428.

Goldstein, Itay and Assaf Razin (2006), “An information-based tradeoff between foreign direct investment and foreign portfolio investment”, Journal of International Economics 70: 271-295.

Goldstein, Itay, Assaf Razin and Hui Tong (2010), "Liquidity, institutional quality and the composition of international equity flows”, NBER Working Paper 15727.

Gordon, Roger H. and A. Lans Bovenberg (1996), "Why is capital so immobile internationally? Possible explanations and implications for capital income taxation”, American Economic Review, Vol. 86(5): 1057-75. 
Granger, Clive J., Bwo-Nung Huang and Chin-Wei Yang (2000),“A bivariate causality between stock prices and exchange rates: evidence from recent Asian flu”, Quarterly Review of Economics and Finance 40:337-54.

Hale, Galina (2007), "Bonds or loans? The effect of macroeconomic fundamentals”, The Economic Journal 117: 196-215.

Hansen, Lars Peter (1982), "Large sample properties of Generalized Method of Moments Estimators”, Econometrica 50, 3, 1029 -54.

Hviding, Ketil, Michael Nowak and Luca A. Ricci (2004), “Can higher reserves help reduce exchange rate volatility?”, IMF Working Paper No. 04/189.

International Monetary Fund (2012), "Macroeconomic policy frameworks for resource-rich developing countries." http://www.imf.org/external/np/pp/eng/2012/082412.pdf

Joyce, Joseph P. (2011), "Financial globalization and banking crises in emerging markets”, Open Economies Review, Vol. 22(5): 875-895.

Kaminsky, Graciela L. and Carmen M. Reinhart (1999), “The twin crises: the causes of banking and balance-of-payments problems”, American Economic Review, Vol. 89(3): 473-500.

Kirabaeva, Koralai and Assaf Razin (2013), “Composition of capital inflows: a survey”, In: Gerard Caprio (ed.), The evidence and impact of financial globalization, Vol. 3, Oxford: Elsevier Inc.

Krugman, Paul (2000), “Fire-Sale FDI,” in: Paul Krugman, Capital flows and the emerging economies: theory, evidence and controversies, Chicago, pp. 43-60.

Lane, Philip R. and Gian Maria Milesi-Ferretti (2000), “External capital structure: theory and evidence”, IMF Working Paper 00/152.

Lane, Philip R. and Gian Maria Milesi-Ferretti (2007), "The external wealth of nations mark II: Revised and extended estimates of foreign assets and liabilities, 1970-2004", Journal of International Economics 73, November: 223-250.

Lane, Philip R. and Gian Maria Milesi-Ferretti (2008), “The drivers of financial globalization”, American Economic Review: Papers \& Proceedings 98(2): 327-332.

Levchenko, Andrei A. and Paolo Mauro (2007), "Do some forms of financial flows help protect against “sudden stops”?”, The World Bank Economic Review 21(3): 389-411.

Li, Jie and Ramkishen S. Rajan (2009), "Can high reserves offset weak fundamentals? A simple model of precautionary demand for reserves”, Economia Internazionale (International Economics), LIX: $317-28$.

Martínez, Lorenza and Alejandro Werner (2002), “The exchange rate regime and the currency composition of corporate debt: the Mexican experience”, Journal of Development Economics, Volume 69(2): 315-334.

Magud, Nicolas, Carmen Reinhart and Kenneth Rogoff (2011), "Capital controls: myth and reality - a portfolio balance approach,” NBER Working Paper 16805.

Malliaropulos, Dimitrios (1998), "International stock return differentials and real exchange rate changes”, Journal of International Money and Finance, Volume 17(3): 493-511.

McKinsey Global Institute (2011), “Mapping global capital market 2011”, McKinsey and Company.

Milesi-Ferretti, Gian-Maria and Cédric Tille (2011), “The great retrenchment: international capital flows during the global financial crisis”, Economic Policy 26(66): 289-346. 
Montiel, Peter, and Carmen M. Reinhart (1999), "Do capital controls and macroeconomic policies influence the volume and composition of capital flows? Evidence from the 1990s", Journal of International Money and Finance, Vol. 18: 619-35.

Obstfeld, Maurice, Jay C. Shambaugh and Alan M. Taylor (2009), "Financials instability, reserves, and central bank swap lines in the panic of 2008", American Economic Review: Papers and Proceedings, Vol. 99(2): 480-486.

Ostry, Jonathan D., Atish R. Ghosh, Karl Habermeier, Marcos Chamon, Mahvash S. Qureshi and Dennis B. S. Reinhardt (2010), “Capital inflows: the role of controls”, IMF Staff Position Note SPN/10/04.

Patro, Dilip K., John K. Wald and Yangru Wu (2013), “Currency devaluation and stock market response: an empirical analysis”, Journal of International Money and Finance, forthcoming.

Portes, Richard, and Hélène Rey (2005), “The determinants of cross-border equity flows”, Journal of International Economics, Vol. 65, Issue 2: 269-296.

Razin, Assaf, Efraim Sadka and Chi-Wa Yuen (1998), “A pecking order of capital inflows and international tax principles”, Journal of International Economics 44: 45-68.

Reinhart, Carmen M. and Kenneth S. Rogoff (2011), "From financial crash to debt crisis”, American Economic Review 101: 1676-1706.

Rogoff, Kenneth (1999), “International institutions for reducing global financial instability”, Journal of Economic Perspectives, Vol. 13, No. 4: 21-42.

Tirole, Jean (2003), “Inefficient foreign borrowing: a dual- and common-agency perspective”, American Economic Review, Vol. 93(5): 1678-1702.

Tong, Hui and Shang-Jin Wei (2011), "The composition matters: capital inflows and liquidity crunch during a global economic crisis”, Review of Financial Studies 24(6): 2023-2052.

Wei, Shang-Jin and Yi Wu (2002), "Negative alchemy? Corruption, composition of capital flows, and currency crises”, in: Sebastian Edwards and Jeffrey A. Frankel (eds.), Preventing currency crises in emerging markets, NBER Books, National Bureau of Economic Research, Inc, pages 461-506.

Wheeler, David And Ashoka Mody (1992), "International investment location decisions: the case of US firms”, Journal of International Economics 33(1-2): 57-76.

Wilson, Berry, Anthony Saunders and Gerard Caprio, Jr. (2000), “Financial fragility and Mexico's 1994 peso crisis: an event-window analysis of market-valuation effects", Journal of Money Credit and Banking 32: 450-473.

Windmeijer, Frank (2005), “A finite sample correction for the variance of linear efficient two-step GMM estimators”, Journal of Econometrics 126: 25-51. 
Table 1: Panel data regression regarding the choice of PEI or FDI in developing countries

\begin{tabular}{|c|c|c|c|c|}
\hline & (1) & $(2)$ & (3) & (4) \\
\hline Stock market capitalization(-1) & $\begin{array}{c}0.655^{* * *} \\
(0.08)\end{array}$ & $\begin{array}{c}0.662^{* * *} \\
(0.09)\end{array}$ & $\begin{array}{c}0.656^{* * *} \\
(0.09)\end{array}$ & $\begin{array}{c}0.650 * * * \\
(0.11)\end{array}$ \\
\hline Institutional quality(-1) & $\begin{array}{c}0.045^{* * *} \\
(0.02)\end{array}$ & $\begin{array}{l}0.021 \\
(0.02)\end{array}$ & $\begin{array}{c}0.033^{*} \\
(0.02)\end{array}$ & $\begin{array}{l}0.026 \\
(0.02)\end{array}$ \\
\hline International reserves(-1) & $\begin{array}{c}0.151^{* * *} \\
(0.05)\end{array}$ & $\begin{array}{c}0.124^{* *} \\
(0.06)\end{array}$ & $\begin{array}{c}0.121^{* *} \\
(0.06)\end{array}$ & $\begin{array}{c}0.153^{* *} \\
(0.07)\end{array}$ \\
\hline Natural resources(-1) & $\begin{array}{l}0.368 \\
(0.33)\end{array}$ & $\begin{array}{l}0.359 \\
(0.36)\end{array}$ & $\begin{array}{l}0.360 \\
(0.36)\end{array}$ & $\begin{array}{l}-0.411 \\
(0.58)\end{array}$ \\
\hline Trade openness(-1) & $\begin{array}{c}-0.004^{* *} \\
(0.00)\end{array}$ & $\begin{array}{c}-0.004^{*} \\
(0.00)\end{array}$ & $\begin{array}{l}-0.003 \\
(0.00)\end{array}$ & $\begin{array}{l}-0.002 \\
(0.00)\end{array}$ \\
\hline World short-term interest rate(-1) & $\begin{array}{c}-0.065^{* * *} \\
(0.02)\end{array}$ & $\begin{array}{c}-0.060 * * * \\
(0.02)\end{array}$ & $\begin{array}{c}-0.059 * * * \\
(0.02)\end{array}$ & $\begin{array}{c}-0.048 * \\
(0.03)\end{array}$ \\
\hline $\operatorname{GDP}(-1)$ & $\begin{array}{c}0.246^{* *} \\
(0.11)\end{array}$ & $\begin{array}{c}0.459 * * * \\
(0.13)\end{array}$ & $\begin{array}{c}0.487 * * * \\
(0.13)\end{array}$ & $\begin{array}{c}0.464 * * * \\
(0.17)\end{array}$ \\
\hline Real GDP growth(-1) & $\begin{array}{l}0.681 \\
(0.65)\end{array}$ & $\begin{array}{l}0.701 \\
(0.67)\end{array}$ & $\begin{array}{l}0.861 \\
(0.67)\end{array}$ & $\begin{array}{l}1.174 \\
(0.80)\end{array}$ \\
\hline Crisis & & $\begin{array}{l}-0.194 \\
(0.13)\end{array}$ & $\begin{array}{l}-0.146 \\
(0.13)\end{array}$ & $\begin{array}{l}-0.137 \\
(0.16)\end{array}$ \\
\hline Mexican crisis 1994 & & $\begin{array}{l}0.203^{*} \\
(0.10)\end{array}$ & $\begin{array}{l}0.142 \\
(0.10)\end{array}$ & $\begin{array}{l}0.069 \\
(0.13)\end{array}$ \\
\hline East Asian crisis 1997 & & $\begin{array}{c}-0.361^{* * *} \\
(0.10)\end{array}$ & $\begin{array}{c}-0.290 * * * \\
(0.10)\end{array}$ & $\begin{array}{c}-0.400 * * * \\
(0.13)\end{array}$ \\
\hline Global Financial Crisis 2008 & & $\begin{array}{c}-0.695 * * * \\
(0.12)\end{array}$ & $\begin{array}{c}-0.711^{* * *} \\
(0.12)\end{array}$ & $\begin{array}{c}-1.176^{* * *} \\
(0.21)\end{array}$ \\
\hline Capital controls(-1) & & & $\begin{array}{l}0.079 \\
(0.05)\end{array}$ & $\begin{array}{l}0.084 \\
(0.06)\end{array}$ \\
\hline Stock market liberalization(-1) & & & & $\begin{array}{c}0.658 * * * \\
(0.16)\end{array}$ \\
\hline Trend & $\begin{array}{l}-0.005 \\
(0.01)\end{array}$ & $\begin{array}{l}0.018 \\
(0.02)\end{array}$ & $\begin{array}{l}0.017 \\
(0.02)\end{array}$ & $\begin{array}{l}0.012 \\
(0.02)\end{array}$ \\
\hline Constant & $\begin{array}{c}-4.318^{*} \\
(2.43)\end{array}$ & $\begin{array}{c}-9.773 * * * \\
(3.01)\end{array}$ & $\begin{array}{c}-10.575^{* * *} \\
(3.00)\end{array}$ & $\begin{array}{c}-9.815^{* *} \\
(3.93)\end{array}$ \\
\hline Number of countries & 76 & 76 & 76 & 48 \\
\hline Adjusted R-squared & 0.12 & 0.16 & 0.17 & 0.28 \\
\hline Observations & 1143 & 1018 & 1010 & 715 \\
\hline
\end{tabular}

Note: The table reports the results of estimating equation (3) with a static panel data fixed-effects regression. Robust errors are in parentheses underneath coefficient estimates. “***, **, *” indicate $1 \%$, $5 \%$, and $10 \%$ level of significance, respectively. 
Table 2: Panel data regression regarding the choice of PEI or FDI of natural resource-rich developing countries

\begin{tabular}{|c|c|c|c|c|}
\hline & (1) & $(2)$ & (3) & (4) \\
\hline Stock market capitalization(-1) & $\begin{array}{c}0.901^{* * *} \\
(0.27)\end{array}$ & $\begin{array}{c}1.020^{* * *} \\
(0.31)\end{array}$ & $\begin{array}{c}1.012^{* * *} \\
(0.31)\end{array}$ & $\begin{array}{l}0.126 \\
(0.55)\end{array}$ \\
\hline Institutional quality(-1) & $\begin{array}{l}0.010 \\
(0.06)\end{array}$ & $\begin{array}{l}-0.048 \\
(0.06)\end{array}$ & $\begin{array}{l}-0.047 \\
(0.06)\end{array}$ & $\begin{array}{l}-0.001 \\
(0.07)\end{array}$ \\
\hline International reserves(-1) & $\begin{array}{l}-0.011 \\
(0.12)\end{array}$ & $\begin{array}{l}0.069 \\
(0.14)\end{array}$ & $\begin{array}{l}0.059 \\
(0.14)\end{array}$ & $\begin{array}{l}0.249 \\
(0.16)\end{array}$ \\
\hline Crude oil price(-1) & $\begin{array}{l}-0.001 \\
(0.01)\end{array}$ & $\begin{array}{l}-0.024 \\
(0.02)\end{array}$ & $\begin{array}{l}-0.023 \\
(0.02)\end{array}$ & $\begin{array}{l}0.004 \\
(0.02)\end{array}$ \\
\hline Natural resources(-1) & $\begin{array}{l}0.423 \\
(0.52)\end{array}$ & $\begin{array}{l}0.359 \\
(0.56)\end{array}$ & $\begin{array}{l}0.340 \\
(0.56)\end{array}$ & $\begin{array}{l}-0.549 \\
(0.92)\end{array}$ \\
\hline Trade openness(-1) & $\begin{array}{l}-0.001 \\
(0.01)\end{array}$ & $\begin{array}{l}0.001 \\
(0.01)\end{array}$ & $\begin{array}{l}0.001 \\
(0.01)\end{array}$ & $\begin{array}{c}0.026 * * \\
(0.01)\end{array}$ \\
\hline World short-term interest rate(-1) & $\begin{array}{c}-0.071^{*} \\
(0.04)\end{array}$ & $\begin{array}{l}0.025 \\
(0.08)\end{array}$ & $\begin{array}{l}0.028 \\
(0.08)\end{array}$ & $\begin{array}{l}-0.061 \\
(0.08)\end{array}$ \\
\hline GDP $(-1)$ & $\begin{array}{l}0.295 \\
(0.34)\end{array}$ & $\begin{array}{l}0.624 \\
(0.40)\end{array}$ & $\begin{array}{l}0.609 \\
(0.40)\end{array}$ & $\begin{array}{l}0.049 \\
(0.57)\end{array}$ \\
\hline Real GDP growth(-1) & $\begin{array}{l}0.310 \\
(1.28)\end{array}$ & $\begin{array}{l}0.572 \\
(1.32)\end{array}$ & $\begin{array}{l}0.808 \\
(1.33)\end{array}$ & $\begin{array}{l}1.337 \\
(1.70)\end{array}$ \\
\hline Crisis & & $\begin{array}{l}-0.284 \\
(0.40)\end{array}$ & $\begin{array}{l}-0.237 \\
(0.40)\end{array}$ & $\begin{array}{c}-0.951 * \\
(0.51)\end{array}$ \\
\hline Mexican crisis 1994 & & $\begin{array}{l}-0.616 \\
(0.45)\end{array}$ & $\begin{array}{l}-0.630 \\
(0.45)\end{array}$ & $\begin{array}{l}0.084 \\
(0.48)\end{array}$ \\
\hline East Asian crisis 1997 & & $\begin{array}{l}-0.564 \\
(0.37)\end{array}$ & $\begin{array}{l}-0.551 \\
(0.37)\end{array}$ & $\begin{array}{l}-0.263 \\
(0.39)\end{array}$ \\
\hline Global Financial Crisis 2008 & & $\begin{array}{c}-0.490 * \\
(0.28)\end{array}$ & $\begin{array}{c}-0.484^{*} \\
(0.28)\end{array}$ & $\begin{array}{l}-0.727 \\
(0.52)\end{array}$ \\
\hline Capital controls(-1) & & & $\begin{array}{l}0.135 \\
(0.10)\end{array}$ & $\begin{array}{l}0.031 \\
(0.10)\end{array}$ \\
\hline Stock market liberalization(-1) & & & & $\begin{array}{c}0.936 * * \\
(0.37)\end{array}$ \\
\hline Trend & $\begin{array}{l}0.019 \\
(0.03)\end{array}$ & $\begin{array}{l}0.151 \\
(0.10)\end{array}$ & $\begin{array}{l}0.154 \\
(0.10)\end{array}$ & $\begin{array}{l}0.011 \\
(0.11)\end{array}$ \\
\hline Constant & $\begin{array}{l}-6.926 \\
-8.208\end{array}$ & $\begin{array}{c}-16.067 * \\
-9.691\end{array}$ & $\begin{array}{l}-15.74 \\
-9.678\end{array}$ & $\begin{array}{c}-1.11 \\
-13.801\end{array}$ \\
\hline $\begin{array}{l}\text { Number of countries } \\
\text { Adjusted R-squared } \\
\text { Observations }\end{array}$ & $\begin{array}{c}20 \\
0.25 \\
286\end{array}$ & $\begin{array}{c}20 \\
0.28 \\
255\end{array}$ & $\begin{array}{c}20 \\
0.29 \\
255\end{array}$ & $\begin{array}{c}10 \\
0.36 \\
146\end{array}$ \\
\hline
\end{tabular}

Note: The table reports the results of estimating equation (3) with a static panel data fixed-effects regression. Robust errors are in parentheses underneath coefficient estimates. “***, **, *” indicate $1 \%$, $5 \%$, and $10 \%$ level of significance, respectively. 
Table 3: Panel data regression regarding the choice of PEI or FDI of non-natural resource-rich developing countries

(1)

$\begin{array}{lc}\text { Stock market capitalization(-1) } & 0.617^{* * *} \\ & (0.09) \\ \text { Institutional quality(-1) } & 0.045^{* *} \\ & (0.02) \\ \text { International reserves(-1) } & 0.234^{* * *} \\ & (0.06) \\ \text { Natural resources(-1) } & -0.381 \\ & (0.51) \\ \text { Trade openness(-1) } & -0.003 \\ & (0.00) \\ \text { World short-term interest rate(-1) } & -0.061^{* * *} \\ & (0.02) \\ \text { GDP(-1) } & 0.214^{*} \\ & (0.12) \\ \text { Real GDP growth(-1) } & 0.781 \\ & (0.76)\end{array}$

Mexican crisis 1994

East Asian crisis 1997

Global Financial Crisis 2008

Capital controls(-1)

Stock market liberalization(-1)

Trend

Constant

Number of countries

Adjusted R-squared

Observations

0.18
(2)

$0.618 * * *$

(0.10)

0.024

(0.02)

$0.156^{* *}$

(0.07)

$-0.045$

(0.60)

$-0.003^{*}$

$(0.00)$

$-0.056 * * *$

(0.02)

$0.412 * * *$

(0.14)

0.908

(0.79)

$-0.181$

(0.14)

$0.318^{* * *}$

(0.11)

$-0.431^{* * *}$

(0.11)

$-0.743^{* * *}$

(0.14)
(3)

(4)

$0.615 * * * \quad 0.703^{* * *}$

(0.09)

$0.037 *$

(0.11)

0.033

(0.02)

(0.02)

$0.155^{* *}$

(0.07)

$-0.022$

(0.60)

$-0.003$

$(0.00)$

$-0.055^{* * *}$

(0.02)

$0.447 * * *$

(0.14)

1.077

(0.80)

$-0.132$

(0.14)

$0.247^{* *}$

(0.12)

$-0.350 * * *$

(0.11)

$-0.762 * * *$

(0.14)

0.055

(0.07)

$0.136^{*}$

(0.08)

$-0.319$

(0.79)

$-0.003$

(0.00)

$-0.051^{*}$

(0.03)

$0.724 * * *$

(0.19)

1.159

(0.92)

$-0.015$

(0.18)

0.135

(0.14)

$-0.410 * * *$

(0.14)

$-1.225^{* * *}$

(0.23)

0.091

(0.08)

$0.600^{* * *}$

(0.18)

$-0.007$

(0.03)

(0.02)

$-9.304 * * *$

(3.27)
$-15.865^{* * *}$

(4.34)

56

38

0.25

0.30

0.24

755

Note: The table reports the results of estimating equation (3) with a static panel data fixed-effects regression. Robust errors are in parentheses underneath coefficient estimates. “***, **, *” indicate 1\%, $5 \%$, and $10 \%$ level of significance, respectively. 
Table 4: GMM type dynamic panel data regression regarding the choice of PEI or FDI in developing countries

(1)

PEI share (-1)

Stock market capitalization(-1)

Institutional quality(-1)

International reserves(-1)

Natural resources(-1)

Trade openness(-1)

World short-term interest rate(-1)

GDP(-1)

Real GDP growth(-1)

Crisis

Mexican crisis 1994

East Asian crisis 1997

Global Financial Crisis 2008

Capital controls(-1)

Stock market liberalization(-1)

Trend

Constant

Number of countries

Hansen

$\operatorname{AR}(1)$

$\operatorname{AR}(2)$

Instruments

Observations
$0.454^{* * *}$

$-0.086^{* * *}$

Note: The table reports the results of estimating equation (4) with dynamic panel data GMM regression. Robust errors are in parentheses underneath coefficient estimates. “***, **, *” indicate $1 \%, 5 \%$, and $10 \%$ level of significance, respectively.
(2)

$(0.10)$

$-0.013$

$(0.14)$

0.052

$(0.04)$

$0.401 * *$

$(0.18)$

$-1.078$

(1.12)

0.008

(0.01)

(0.02)

0.304*

(0.17)

0.702

(0.54)

(

(3) (4)

$0.504^{* *}$

(0.09)

$0.469 * * *$

(0.10)

$0.447^{* * *}$

$-0.223$

$-0.190$

(0.09)

0.051

(0.16)

(0.17)

(0.16)

0.021

0.028

0.008

(0.04)

(0.04)

$0.384^{* *}$

$0.404^{* *}$

0.281

(0.17)

(0.17)

(0.18)

-4.001 *

$-4.356 *$

(1.97)

(2.12)

(2.40)

0.004

0.002

(0.01)

$-0.024$

(0.01)

(0.01)

$-0.025$

$-0.026$

(0.03)

(0.03)

0.258 *

$0.322 * *$

0.252

(0.14)

(0.17)

0.682

0.900

1.101

(0.59)

(0.61)

(0.81)

$-0.257$

$-0.249$

$-0.305$

(0.21)

(0.22)

(0.25)

-0.380 **

(0.16)

$-0.411^{* * *}$

(0.11)

$-0.675^{* * *}$

(0.11)

$-0.342 * *$

(0.16)

-0.331 **

(0.16)

$-0.397 * * *$

(0.13)

$-0.685^{* * *}$

(0.11)

$0.075 *$

$-0.444^{* * *}$

(0.15)

$-1.195^{* * *}$

(0.17)

0.066

(0.04)

(0.04)

0.015

(0.41)

0.045

(0.04)

$-4.307$

$-4.470$

(3.85)

(3.54)

(3.54)

(3.51)

48

76
60.13
$-4.74^{* * *}$
0.53
70

76

76

39.58

$-4.32 * * *$

$-4.21 * * *$

$-3.81 * * *$

0.45

0.30

0.46

69

70

708

1141

1016

1002 
Table 5: Dynamic regressions (GMM) for natural resource-rich developing countries

\begin{tabular}{|c|c|c|c|c|}
\hline & (1) & (2) & (3) & (4) \\
\hline \multirow[t]{2}{*}{ PEI share $(-1)$} & $0.288 *$ & 0.231 & 0.248 & $0.331 *$ \\
\hline & $(0.16)$ & $(0.19)$ & $(0.20)$ & $(0.19)$ \\
\hline \multirow[t]{2}{*}{ Stock market capitalization(-1) } & -0.012 & 0.101 & 0.114 & -0.009 \\
\hline & $(0.15)$ & $(0.27)$ & $(0.28)$ & $(0.64)$ \\
\hline \multirow[t]{2}{*}{ Institutional quality(-1) } & 0.025 & 0.017 & 0.009 & $-0.156 * *$ \\
\hline & $(0.05)$ & $(0.07)$ & $(0.07)$ & $(0.08)$ \\
\hline \multirow[t]{2}{*}{ International reserves(-1) } & -0.115 & -0.062 & -0.051 & 0.434 \\
\hline & $(0.18)$ & $(0.27)$ & $(0.27)$ & $(0.31)$ \\
\hline \multirow[t]{2}{*}{ Crude oil price(-1) } & $-0.011 *$ & -0.023 & -0.025 & -0.021 \\
\hline & $(0.01)$ & $(0.02)$ & $(0.02)$ & $(0.02)$ \\
\hline \multirow[t]{2}{*}{ Natural resources(-1) } & 1.273 & 0.224 & 0.301 & 0.298 \\
\hline & $(0.91)$ & $(0.92)$ & $(0.89)$ & $(0.91)$ \\
\hline \multirow[t]{2}{*}{ Trade openness(-1) } & 0.012 & 0.030 & 0.031 & $0.027^{* * *}$ \\
\hline & $(0.01)$ & $(0.02)$ & $(0.02)$ & $(0.01)$ \\
\hline \multirow[t]{2}{*}{ World short-term interest rate(-1) } & -0.038 & -0.002 & 0.005 & 0.010 \\
\hline & $(0.03)$ & $(0.04)$ & $(0.04)$ & $(0.04)$ \\
\hline \multirow[t]{2}{*}{ GDP(-1) } & 0.267 & 0.623 & 0.691 & $0.868^{* *}$ \\
\hline & $(0.26)$ & $(0.41)$ & $(0.43)$ & $(0.42)$ \\
\hline \multirow[t]{2}{*}{ Real GDP growth(-1) } & $2.810 * * *$ & 2.167 & 2.223 & $3.636^{* *}$ \\
\hline & $(1.08)$ & $(1.35)$ & $(1.37)$ & $(1.57)$ \\
\hline \multirow[t]{2}{*}{ Crisis } & & $-0.794 * *$ & $-0.769 * *$ & -0.351 \\
\hline & & $(0.36)$ & $(0.36)$ & $(0.44)$ \\
\hline \multirow[t]{2}{*}{ Mexican crisis 1994} & & -0.306 & -0.333 & 0.011 \\
\hline & & $(0.21)$ & $(0.21)$ & $(0.25)$ \\
\hline \multirow[t]{2}{*}{ East Asian crisis 1997} & & $-0.394^{* *}$ & $-0.378^{*}$ & -0.455 \\
\hline & & $(0.20)$ & $(0.21)$ & $(0.28)$ \\
\hline \multirow[t]{2}{*}{ Global Financial Crisis 2008} & & $-0.585 * *$ & $-0.592 * *$ & $-0.799 *$ \\
\hline & & $(0.24)$ & $(0.25)$ & $(0.42)$ \\
\hline \multirow[t]{2}{*}{ Capital controls(-1) } & & & 0.065 & -0.025 \\
\hline & & & $(0.06)$ & $(0.05)$ \\
\hline \multirow[t]{2}{*}{ Stock market liberalization(-1) } & & & & 0.508 \\
\hline & & & & $(0.39)$ \\
\hline \multirow[t]{2}{*}{ Trend } & 0.027 & 0.088 & $0.092 *$ & 0.034 \\
\hline & $(0.03)$ & $(0.06)$ & $(0.06)$ & $(0.05)$ \\
\hline \multirow[t]{2}{*}{ Constant } & -8.010 & -17.581 & -19.341 & $-20.882 *$ \\
\hline & $(6.70)$ & $(11.76)$ & (12.35) & $(11.12)$ \\
\hline Number of countries & 20 & 20 & 20 & 10 \\
\hline Hansen & 11.67 & 9.93 & 6.35 & 0.01 \\
\hline $\operatorname{AR}(1)$ & $-2.91 * * *$ & $-2.47 * *$ & $-2.54 * *$ & $-2.15^{* *}$ \\
\hline $\operatorname{AR}(2)$ & -0.49 & -0.72 & -0.86 & -0.86 \\
\hline Instrument & 70 & 68 & 69 & 70 \\
\hline Observations & 285 & 254 & 253 & 144 \\
\hline
\end{tabular}

Note: The table reports the results of estimating equation (4) with dynamic panel data GMM regression. Robust errors are in parentheses underneath coefficient estimates. “***, **, *” indicate $1 \%, 5 \%$, and $10 \%$ level of significance, respectively. 


\begin{tabular}{|c|c|c|c|c|}
\hline & (1) & (2) & (3) & (4) \\
\hline PEI share $(-1)$ & $\begin{array}{c}0.479 * * * \\
(0.10)\end{array}$ & $\begin{array}{c}0.520^{* * *} \\
(0.10)\end{array}$ & $\begin{array}{c}0.511^{* * *} \\
(0.10)\end{array}$ & $\begin{array}{c}0.494^{* * *} \\
(0.09)\end{array}$ \\
\hline Stock market capitalization(-1) & $\begin{array}{l}-0.114 \\
(0.14)\end{array}$ & $\begin{array}{l}-0.165 \\
(0.16)\end{array}$ & $\begin{array}{l}-0.157 \\
(0.17)\end{array}$ & $\begin{array}{l}-0.019 \\
(0.15)\end{array}$ \\
\hline Institutional quality(-1) & $\begin{array}{c}0.066^{*} \\
(0.04)\end{array}$ & $\begin{array}{l}0.049 \\
(0.04)\end{array}$ & $\begin{array}{l}0.046 \\
(0.04)\end{array}$ & $\begin{array}{l}0.029 \\
(0.04)\end{array}$ \\
\hline International reserves(-1) & $\begin{array}{c}0.512^{* * *} \\
(0.20)\end{array}$ & $\begin{array}{c}0.398^{* *} \\
(0.17)\end{array}$ & $\begin{array}{c}0.413^{* *} \\
(0.17)\end{array}$ & $\begin{array}{c}0.390^{* *} \\
(0.17)\end{array}$ \\
\hline Natural resources(-1) & $\begin{array}{l}-0.183 \\
(1.46)\end{array}$ & $\begin{array}{l}-1.959 \\
(1.62)\end{array}$ & $\begin{array}{l}-2.055 \\
(1.62)\end{array}$ & $\begin{array}{l}-2.670 \\
(2.05)\end{array}$ \\
\hline Trade openness(-1) & $\begin{array}{l}0.006 \\
(0.01)\end{array}$ & $\begin{array}{l}0.002 \\
(0.01)\end{array}$ & $\begin{array}{l}0.002 \\
(0.01)\end{array}$ & $\begin{array}{l}0.004 \\
(0.00)\end{array}$ \\
\hline World short-term interest rate(-1) & $\begin{array}{c}-0.097^{* * *} \\
(0.03)\end{array}$ & $\begin{array}{c}-0.048^{* *} \\
(0.02)\end{array}$ & $\begin{array}{c}-0.045^{*} \\
(0.02)\end{array}$ & $\begin{array}{l}-0.044 \\
(0.03)\end{array}$ \\
\hline GDP(-1) & $\begin{array}{c}0.523^{* * *} \\
(0.18)\end{array}$ & $\begin{array}{c}0.498^{* * *} \\
(0.13)\end{array}$ & $\begin{array}{c}0.496 * * * \\
(0.13)\end{array}$ & $\begin{array}{c}0.435^{* * *} \\
(0.17)\end{array}$ \\
\hline Real GDP growth(-1) & $\begin{array}{l}-0.050 \\
(0.74)\end{array}$ & $\begin{array}{l}-0.240 \\
(0.71)\end{array}$ & $\begin{array}{l}-0.044 \\
(0.75)\end{array}$ & $\begin{array}{l}-0.163 \\
(0.78)\end{array}$ \\
\hline Crisis & & $\begin{array}{l}-0.292 \\
(0.20)\end{array}$ & $\begin{array}{l}-0.282 \\
(0.20)\end{array}$ & $\begin{array}{l}-0.390 \\
(0.26)\end{array}$ \\
\hline Mexican crisis 1994 & & $\begin{array}{c}-0.305^{* *} \\
(0.14)\end{array}$ & $\begin{array}{c}-0.318^{* *} \\
(0.14)\end{array}$ & $\begin{array}{c}-0.276 * \\
(0.14)\end{array}$ \\
\hline East Asian crisis 1997 & & $\begin{array}{c}-0.310^{* * *} \\
(0.09)\end{array}$ & $\begin{array}{c}-0.283^{* * *} \\
(0.10)\end{array}$ & $\begin{array}{c}-0.368 * * \\
(0.15)\end{array}$ \\
\hline Global Financial Crisis 2008 & & $\begin{array}{c}-0.739 * * * \\
(0.12)\end{array}$ & $\begin{array}{c}-0.730^{* * *} \\
(0.11)\end{array}$ & $\begin{array}{c}-1.166^{* * *} \\
(0.18)\end{array}$ \\
\hline Capital controls(-1) & & & $\begin{array}{c}0.093^{*} \\
(0.05)\end{array}$ & $\begin{array}{l}0.087 \\
(0.06)\end{array}$ \\
\hline Stock market liberalization(-1) & & & & $\begin{array}{l}-0.354 \\
(0.44)\end{array}$ \\
\hline Trend & $\begin{array}{c}-0.079 * * * \\
(0.03)\end{array}$ & $\begin{array}{l}0.001 \\
(0.02)\end{array}$ & $\begin{array}{l}-0.001 \\
(0.02)\end{array}$ & $\begin{array}{l}0.005 \\
(0.03)\end{array}$ \\
\hline Constant & $\begin{array}{c}-9.778 * * \\
(3.84)\end{array}$ & $\begin{array}{c}-10.115^{* * *} \\
(3.08)\end{array}$ & $\begin{array}{c}-10.050^{* * *} \\
(2.92)\end{array}$ & $\begin{array}{c}-8.492 * * \\
(3.84)\end{array}$ \\
\hline Number of countries & 56 & 56 & 56 & 38 \\
\hline Hansen & 49.18 & 44.48 & 43.67 & 29.33 \\
\hline $\operatorname{AR}(1)$ & $-4.11^{* *}$ & $-3.85^{* *}$ & $-3.74 * *$ & $-3.44^{* *}$ \\
\hline $\operatorname{AR}(2)$ & 1.45 & 1.37 & 1.38 & 1.23 \\
\hline Instrument & 70 & 68 & 69 & 70 \\
\hline Observations & 856 & 762 & 749 & 564 \\
\hline
\end{tabular}

Note: The table reports the results of estimating equation (4) with dynamic panel data GMM regression. Robust errors are in parentheses underneath coefficient estimates. “***, **, *” indicate $1 \%, 5 \%$, and $10 \%$ level of significance, respectively. 
Figure 1: International reserves and the composition of equity capital inflows
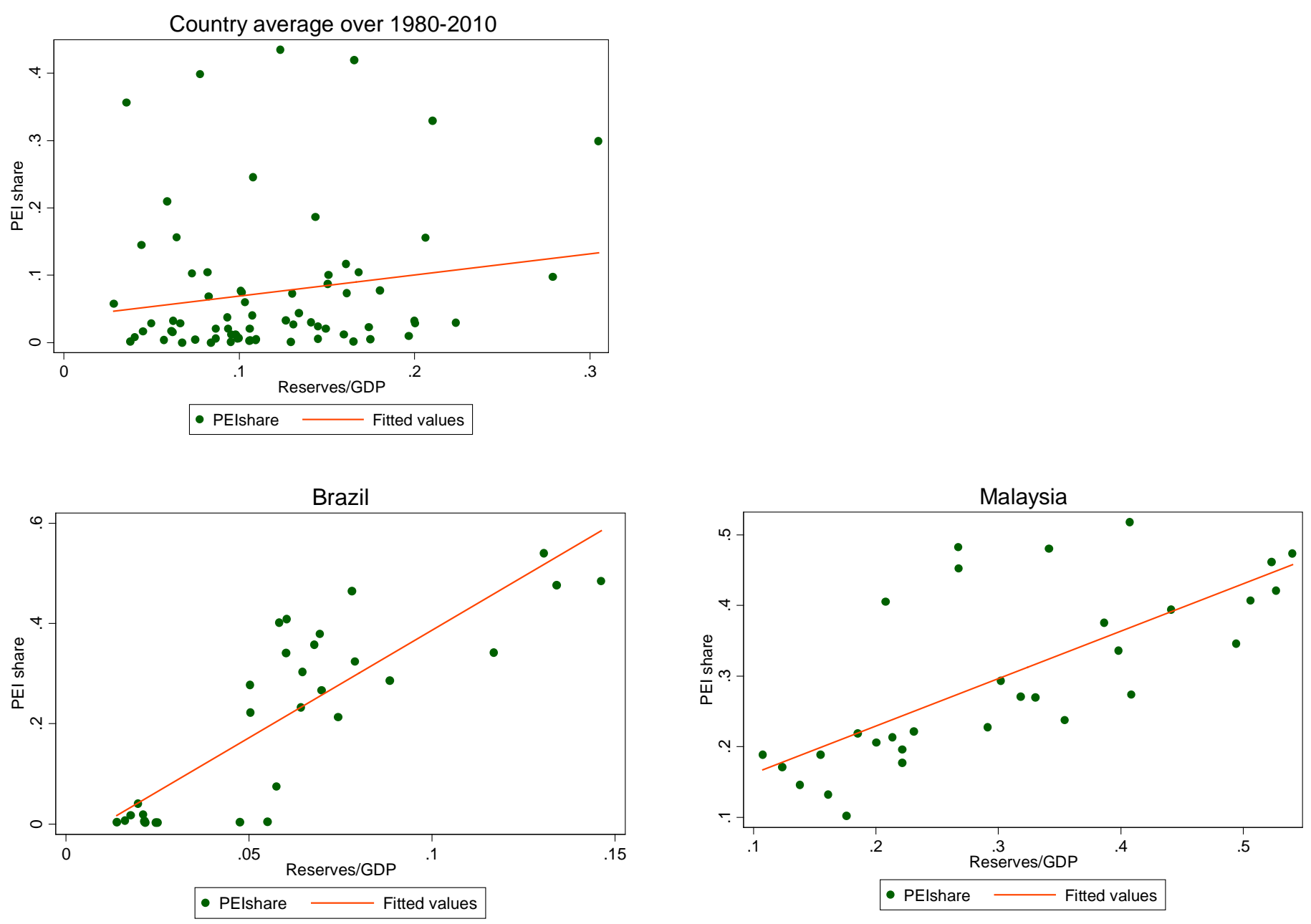
Figure 2: PEI relative to FDI in industrial and developing countries

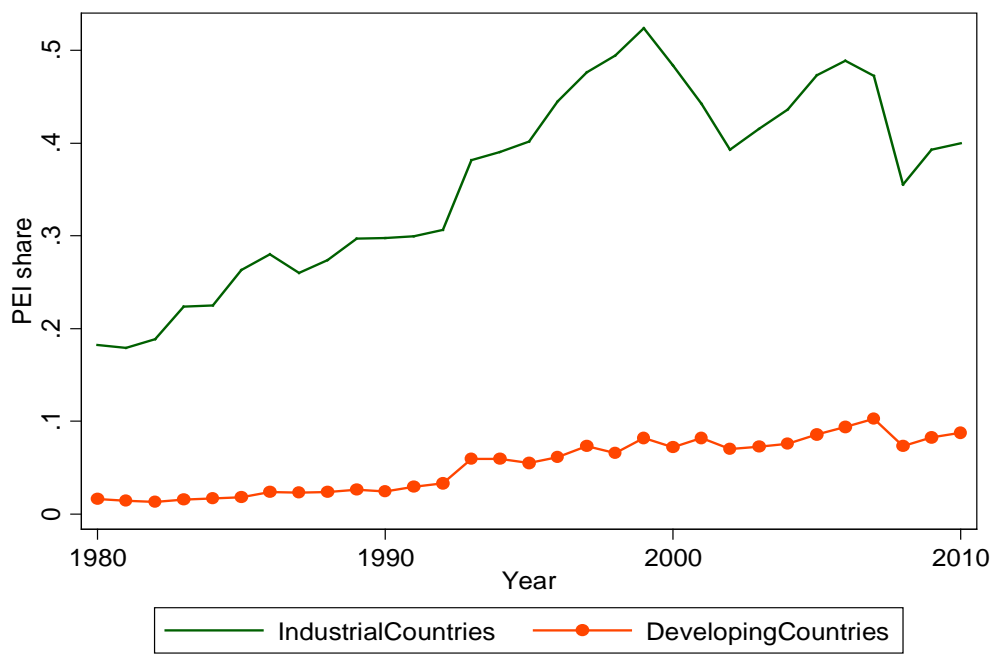

Figure 3: The flow of FDI and PEI in natural resource countries

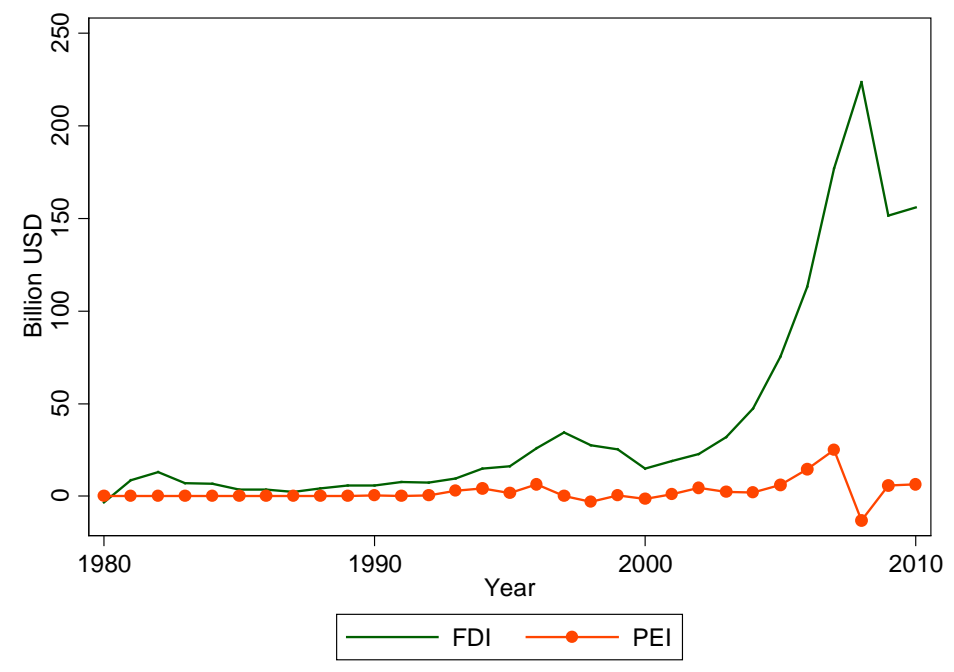


Figure 4: International reserves (average) in natural resource-rich countries

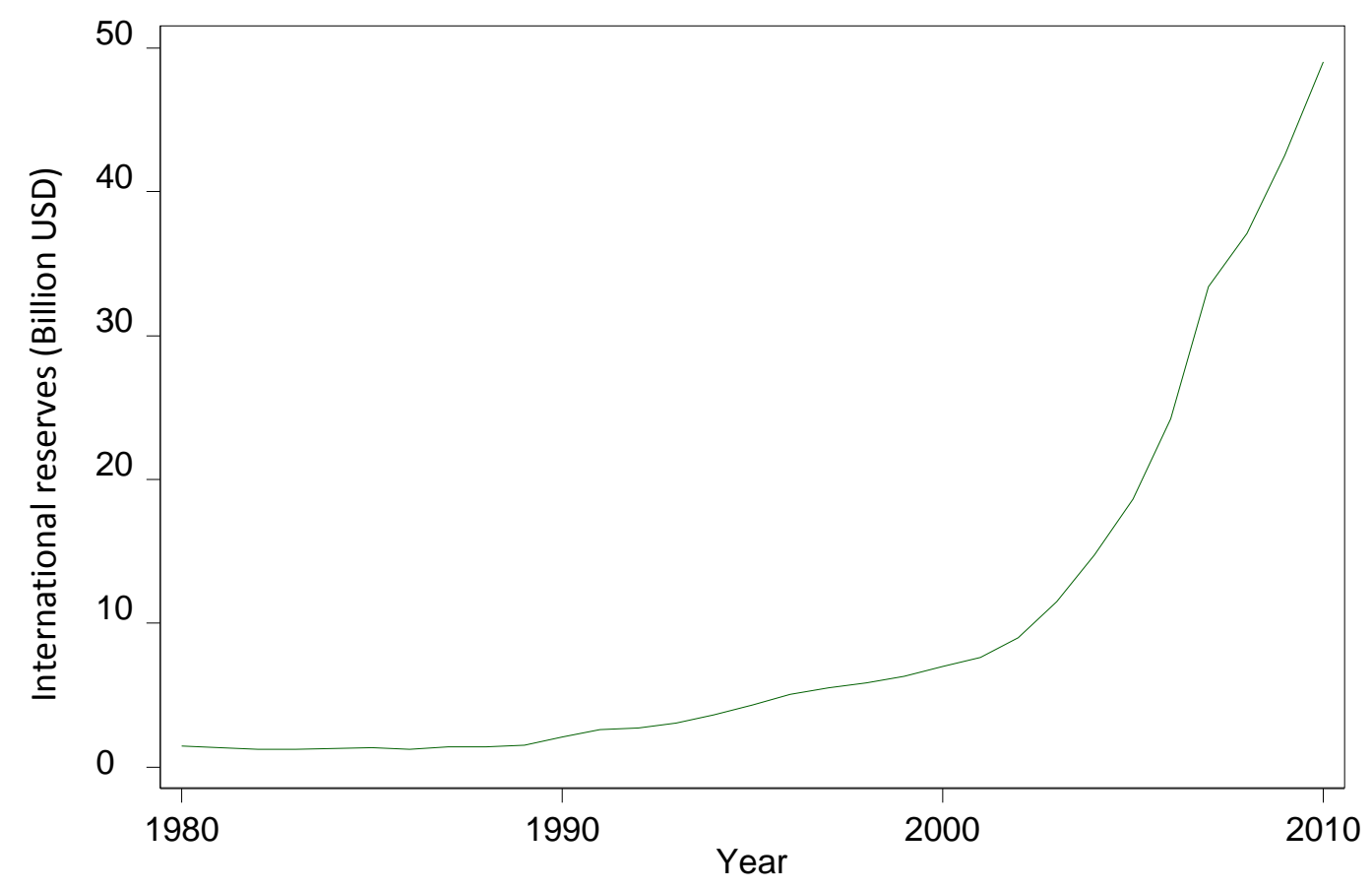

